\title{
Influence of the Adaptation of Balconies to Loggias on the Lighting Climate inside an Apartment Building under Cloudy Sky
}

\author{
Erika Dolníková $^{1} \mathbb{D}$, Dušan Katunský $^{1, * \mathbb{D}}$, Zuzana Miňová ${ }^{1}$ and Bystrík Dolník $^{2} \mathbb{D}$ \\ 1 Department of Architecture and Building Structures, Faculty of Civil Engineering, Technical University of \\ Kosice, 04001 Kosice, Slovakia; erika.dolnikova@tuke.sk (E.D.); zuzana.minova@tuke.sk (Z.M.) \\ 2 Department of Electric Power Engineering, Faculty of Electrical Engineering and Informatics, Technical \\ University of Kosice, 04001 Kosice, Slovakia; bystrik.dolnik@tuke.sk \\ * Correspondence: dusan.katunsky@tuke.sk; Tel.: +421-055-602-4157
}

Citation: Dolníková, E.; Katunský, D.; Miňová, Z.; Dolník, B. Influence of the Adaptation of Balconies to Loggias on the Lighting Climate inside an Apartment Building under Cloudy Sky. Sustainability 2021, 13, 3106. https://doi.org/10.3390/su13063106

Academic Editors: Lambros T. Doulos and Aris Tsangrassoulis

Received: 7 February 2021

Accepted: 9 March 2021

Published: 12 March 2021

Publisher's Note: MDPI stays neutral with regard to jurisdictional claims in published maps and institutional affiliations.

Copyright: (c) 2021 by the authors. Licensee MDPI, Basel, Switzerland. This article is an open access article distributed under the terms and conditions of the Creative Commons Attribution (CC BY) license (https:/ / creativecommons.org/licenses/by/ $4.0 /)$.

\begin{abstract}
The reconstruction of balconies and loggias is a key element of the renovation of apartment buildings. Artificial light will never replace natural light. Every day, one must make full use of the potential of daylight and enjoy an advantage—-free-of-charge natural light entering the interior. When renovating balconies, people often change the character of this protruding structure from a façade to a loggia. This is also the subject of this paper. For the evaluation of the daylighting conditions prevailing in residential building, the Daylight Factor (DF) was considered as the parameter for indicating the quantity of admitted daylight. The DF values and illuminance-CIE overcast sky were calculated using DIALux 9.1 software. The aim of the paper is to compare two variants of the level of daylight in the rooms of the residential building. One option to bring in even more natural light than a window is a variant with balconies. Loggias are satisfactory in terms of static and thermal technology, but daylight conditions are deteriorating. The article provides an insight into the solution of the renovation of balconies and loggias in a specific apartment building. The result shows their influence on changes in the conditions of natural daylight in the interior of two selected rooms.
\end{abstract}

Keywords: balcony; loggia; daylighting; simulation; environment; residential building

\section{Introduction}

People are spending more and more time indoors and losing outdoor direct contact with the sun's rays. The importance of daylight consists of three basic dimensions' the field of health, the field of performance, and the feeling of well-being [1,2]. The "Indoor Generation" is taking the health risk of spending more time inside. People do not fully comprehend the sheer amount of time they are spending inside. This detachment from the natural world—and natural sunlight, specifically—can have negative health impacts and can even have deleterious effects as serious as respiratory problems or seasonal affective disorder. Daylight has a large influence on environmental conditions to improve ambience, visual comfort, well-being, and the health of occupants [3-7].

Neuroscientist and lecturer of medicine at Harvard Medical School, Steven Lockley explains that light, as an "acute stimulant that directly alerts the brain," can affect sleep, alertness, and human productivity. If you are exposed to brighter and bluer light in the daytime, then you get a better stimulant effect. You will be more alert and have better cognitive function. A potential solution to the disruptiveness of indoor living is a form of architectural design - the Circadian House [3-7].

Approaches to daylight design are diverse, depending on many facts, but their goal is the same-to provide optimal solutions for daylighting in building interiors [8]. The influence of lighting on the mental and physical state of a person is now generally known and recognized. When designing interior spaces, it is therefore necessary to create adequate 
lighting conditions for their users resulting from the parameters of visual tasks, i.e., the so-called visual well-being $[9,10]$.

However, visual comfort is not only dependent on the intensity of light but also, for example, on its quality or the color scheme of the interior [11,12]. Balconies produce impacts in four factors that contribute to the indoor environmental quality (thermal, visual, acoustic comfort, and indoor air quality) [13-15]. The light reflectance value is an important parameter when the main part of the daylight contribution comes from the internally reflected component as in the case of a deep and long balcony [16,17]. The authors of [18] developed a framework called the residential daylight score. This study also notes that research on daylighting focuses on office spaces, with limited study on residential spaces [18]. The authors of [19-21] found that there is limited significant proof for the link between daylight and health.

According to the authors of [22] the important attributes for design in residential buildings are quality of view and brightness of surfaces. The authors of [20] reported that external obstruction is an important physical parameter affecting luminous comfort. Furthermore, this study noted that for a moderate circadian rhythm external obstruction should have a value of 0.3 for $75 \%$ of the year. This study also reported that a WWR (window-wall ratio) of $60 \%$ is required in a room with a depth of 4-6 $\mathrm{m}$ [23,24]. Morning light exposure (period 6 a.m.-10 a.m.) is important for circadian rhythm. It is a biological rhythm with a period of 20-28 h (Latin circa = "around", "during", dies = "day"). Circadian rhythm is one of the biorhythms, i.e., fluctuations in activity and vigilance, most often with a daily, monthly, or annual period. Chronobiology deals with rhythms of various lengths. It is important for organisms that the circadian rhythm be aligned with the rhythm of day and night. In humans, a decrease in daylight causes an increase in the level of the hormone melatonin, which facilitates sleep. The course of the circadian rhythm itself has an effect on the performances of individual people [25].

Flats in prefabricated houses have become more and more popular in recent years; their prices are rising, and housing standards are rising along with them. Residents of housing estates expect from the modernization not only savings on heating but also enlargement of the balcony or loggia and beautification of the external appearance [26,27]. Balconies have become decorative features, repeated at regular intervals across a façade, they create a strong sense of coherence and unity in the design. Over years they not only got larger but they have also taken a variety of forms. Some with at least one solid side wall for privacy or with screens or there are full-height railings - often on the side in shade or on the side away from the better view out-and these screens are often combined with built-in troughs for plants [28].

In apartment buildings in the late 19th and early 20th century, only some apartments were given balconies. Perhaps those on the corner or in the center-so the balconies were really just decorative, to "articulate" or add interest to the façade. Most are too shallow to be used for anything more than a few plants and are certainly not intended to be used by the tenants for sitting outside [28]. However, by the 1930s it became common for every apartment or at least the majority of apartments in a block to have a balcony and, in some buildings, this proliferation of small balconies dominates the design of the facade to the point where the balconies, when seen from the street, take on the character of a pattern or texture across the whole front. Balconies in the 1930s and later were seen as important private outdoor space and very important for bringing fresh air and as much light as possible into an apartment [28].

Horizontal structures protruding from the vertical perimeter wall into free space, e.g., balconies or loggias form an important architectural element of buildings. In addition to fulfilling an aesthetic function, they are also used for resting or for growing ornamental or useful plants. The reconstruction of balconies and loggias is a key element of the renovation of apartment buildings. Damage is often extensive and also affects the static safety and functional properties of the buildings. Figure 1 illustrates how the different parameters affect the daylight of a side-lighted workspace [29]. 


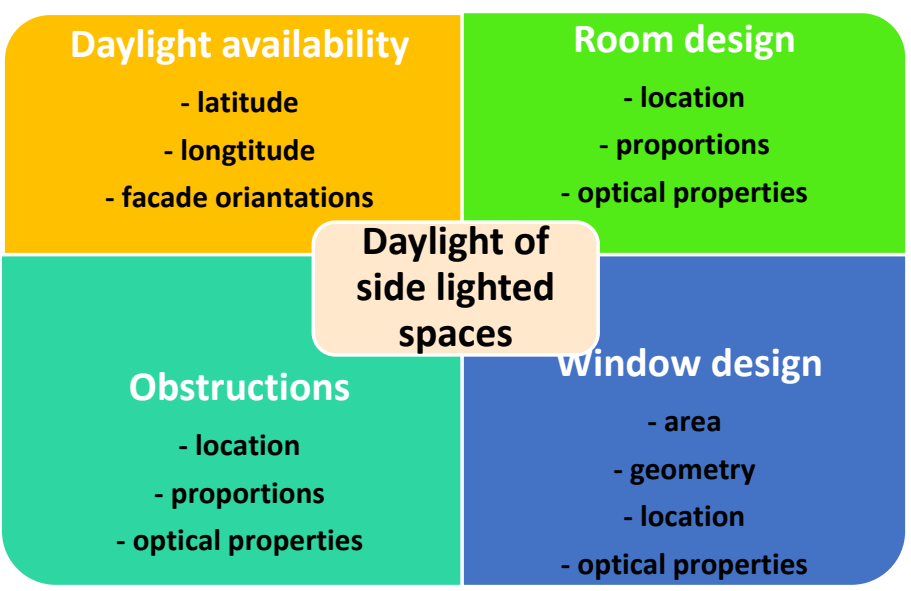

Figure 1. Parameters influencing the daylight of side-lighted spaces (according to [29]).

Balconies and loggias have become a very common feature of prefabricated flats, and the inhabitants use them mainly for recreation and leisure. In terms of function, the loggia is comparable to a balcony. The differences are mainly in the degree of protection against atmospheric influences, which is higher for loggias. This fact is important not only from the point of view of construction protection but also from the point of view of user comfort. The disadvantages of the loggia compared to the balcony are worse view and less visual connection with the surrounding environment [30].

The balcony is a horizontal planar structure protruding from the perimeter wall in front of the building. It is accessible from inside of the building. At least part of the decisive supporting structure (cantilever plate, supporting cantilever beams) statically acts as a bracket, or the whole structure is suspended in front of the perimeter wall. The construction of the balcony is usually open-type on three sides. The loggia is a structure accessible from inside of the building. The horizontal support plate statically acts as a simple plate and is supported by vertical walls, columns, or through frames. It is usually bounded on three sides by walls [31].

However, when designing balconies and loggias, it is good to be aware of, for example, their influence on daylight. By designing a horizontal shading barrier such as a balcony panel above the window opening, the interior will be shaded, and thus the level of daylight in the room will be reduced and the quality of the indoor environment will be degraded. The brightness of the sky at the zenith is always higher than the brightness on the horizon. In the case of winter cloudy skies with dark terrain, this difference is threefold [32]. It follows from these facts that placing the balcony structure above the window opening means that the brightest part of the sky will be shaded and thus the largest source of daylight will be shaded. From the current knowledge, it can be said that the difference between dark- and light-painted loggia can be up to about 30\% of the value of the daylight factor. However, this value does not apply in general and always depends on the overall geometry of the room and the external shading obstacles [33]. The information provided has been obtained from several contributions in the recent past.

The effect of the reflection of the façade on the outdoor microclimate can be seen in reference [34], where an Italian case study is presented in the journal Sustainable Cities and Society. Private outdoor spaces-balconies and loggias in Latvia-are the subject dealt with by book author J. Prikulis [35]. The issues concerning the design of loggia elements are addressed in reference [36] and those concerning balconies in reference [37]. On balconies, it is possible to use parapet masonry for the application of photoelectric cells [38]. Balconies affect thermal comfort [39], their glazing not only affects the perception of daylight but also affects the thermal-humidity climate in flats in prefabricated buildings [40]. These glazed balconies act as passive greenhouse systems. Their potential use is reported in Poland, for example, reference [41]. An overall study of the impact of balconies on the quality of the environment in flats as well as the overall renovation of the building, taking 
into account the sustainability of construction in the BIM environment, was presented last year in the journal Sustainability [42]. In addition to balconies, as we present in this article, another option is the loggia through which it is possible to get access to the exterior. Balconies, loggias, and various thin-walled units in large, prefabricated buildings are described in reference [43]. Modifications (for example) of loggia extensions impact daylight and sunlight [44] as well as possible thermal bridges [45] or the overall airtightness of buildings [46]. Modifications of these structural elements, i.e., balconies and loggias, affect the impact of natural lighting, energy savings, and visual comfort. These aspects are being explored in collaboration in collective housing [47]. The latter is a case study in the context of existing Algerian buildings.

Some literary sources use dynamic metrics (daylight autonomy, useful daylight, etc.). They are based on local series of climate data because they are able to capture the peculiarities of the local climate, including daylight and seasonal changes in daylight. Such examples can be found in the evaluation of lighting conditions in Italy $[48,49]$.

The method presented a practical procedure, which can be easily implemented in computer software, to derive lighting on the surfaces of urban canyons with balconies in sunny areas, allowing the designer to explore a number of options found in [50]. The development of this method is based on the division of an urban canyon into a series of interconnected structural elements for the purpose of lighting calculations using flow transmission equations.

In Slovakia, almost 70\% of the total number of apartment buildings are built with panel technology. It can be said that, in such panel technologies, most apartments are equipped with balconies. Their service life is not high, so in the last period as well as in the present, a number of prefabricated houses are being reconstructed. During the reconstruction, the balconies are sometimes changed to loggias. This fact is also the subject of this paper. There are several repetitive flats on floors and sections in the housing estate Kosice II west (see Figure 2).
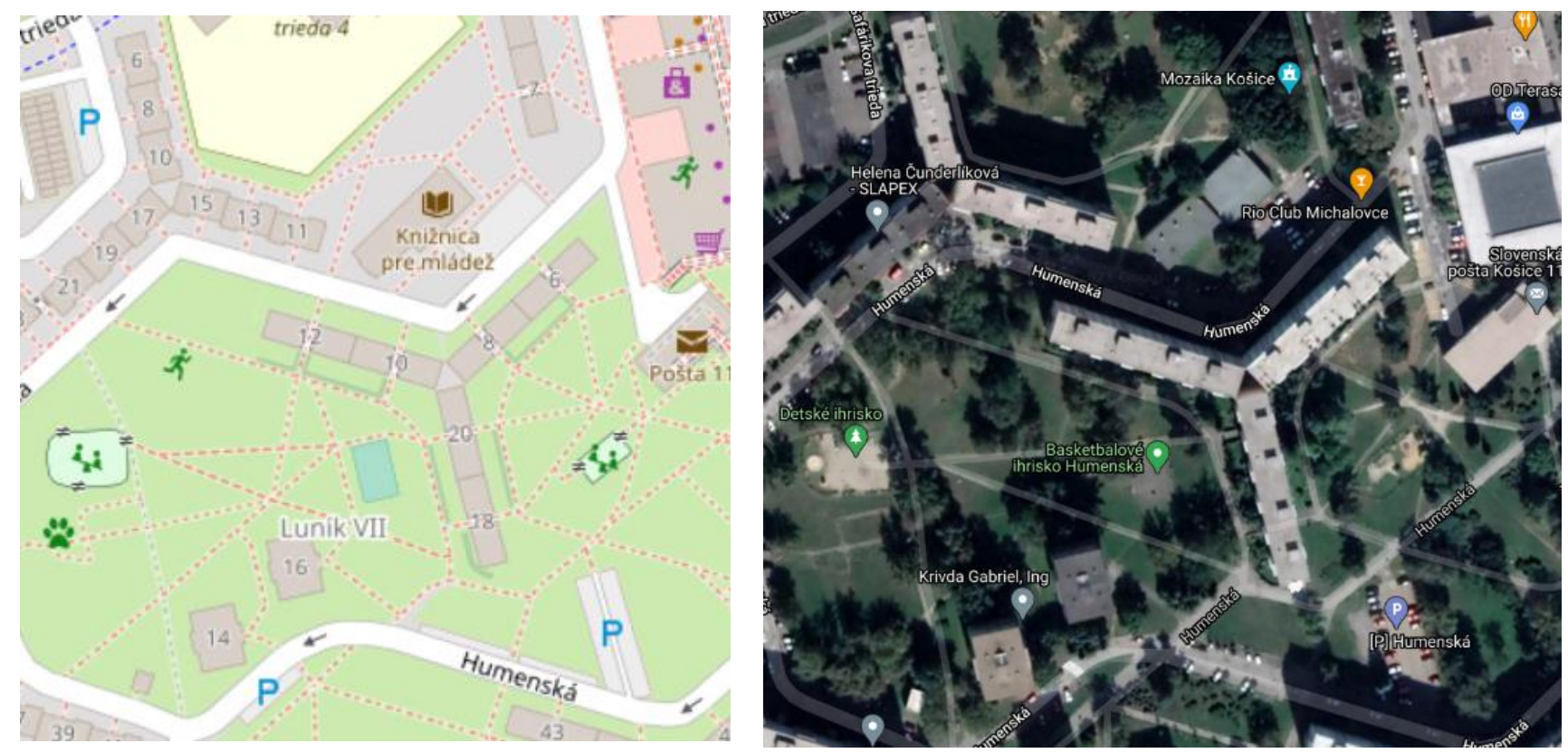

Figure 2. Situation of selected apartment building in map.

\section{Materials and Methods}

Many residents of prefabricated houses are reconstructing or renovating their apartments. As part of the renovation, some use the option to convert the balcony into a loggia. The reasons are varied: increased protection of children or personal intimacy, or prevention of excessive glare from the side walls of loggias. However, these facts have consequences 
for the deterioration of daylight levels. Therefore, the purpose and goal is to compare the level of daylight in one apartment unit in Slovakia, in the town of Kosice, Humenska (street) 49 , where two rooms have balconies, which after modification will be turned into loggias.

\subsection{Description of the Selected Apartment}

In this study, two design variants were tested: two rooms with a balcony and two rooms with a loggia. Room 1 is south oriented. Room 4 is east oriented (see Figure 3). These are south- and east-facing balconies, which will be transformed into loggias after renovation. Figure 3 shows the layout of the apartment in a position such as the results from the simulations. This is to make the reader better oriented in the text to have a better image of the situation.

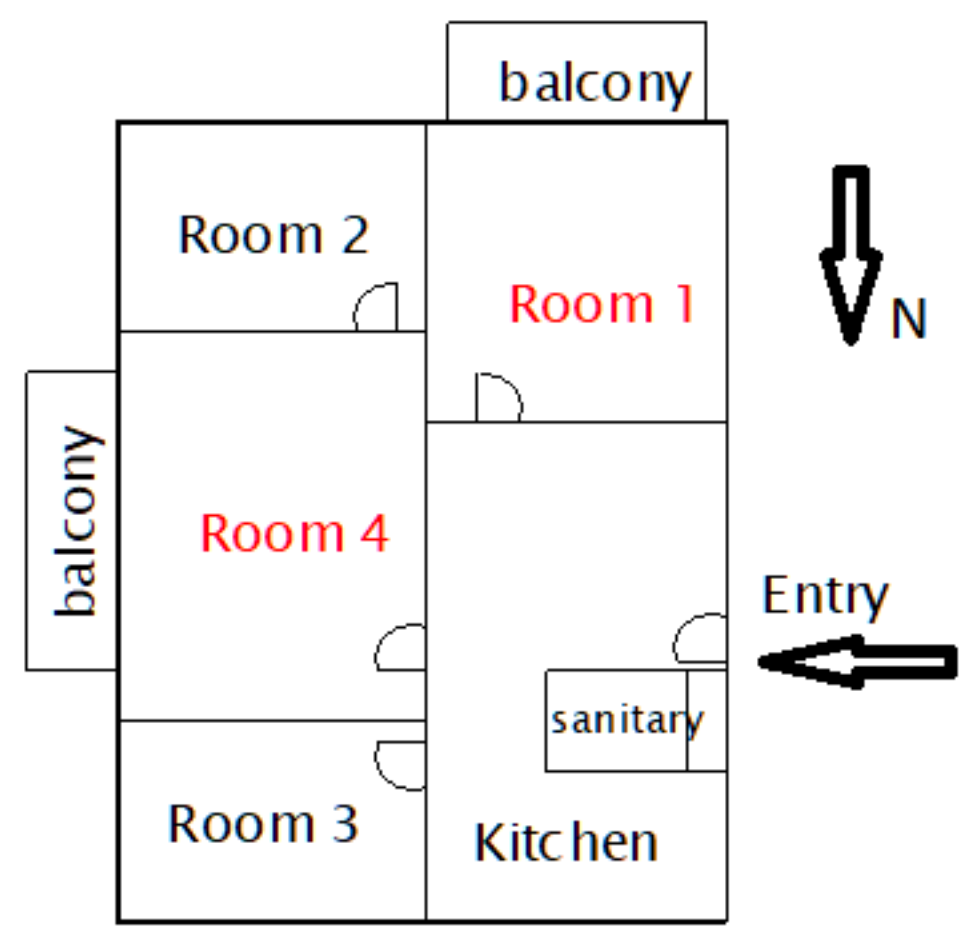

Figure 3. Floor plan of the apartment with the marking of test rooms.

The tested rooms in the selected apartment building are illuminated by side windows and glass doors. The following methodology applies in this article:

$>$ Measuring the value of daylight in rooms

- with balcony,

- with loggia,

$>$ Calculated and simulated daylight situations,

$>$ Confrontation of measured and calculated Daylight Factor (DF) values,

$>$ Results of daylight simulations for two alternatives with balcony and loggia.

Recommendations and conclusions.

A view of the building with balconies before reconstruction and loggias after reconstruction can be seen in Figure 4 .

\subsection{Research Methodology}

The description of individual steps in the evaluation of lighting conditions in the selected two rooms of the selected apartment in the Kosice II housing estate can be seen in the development diagram in Figure 5. 


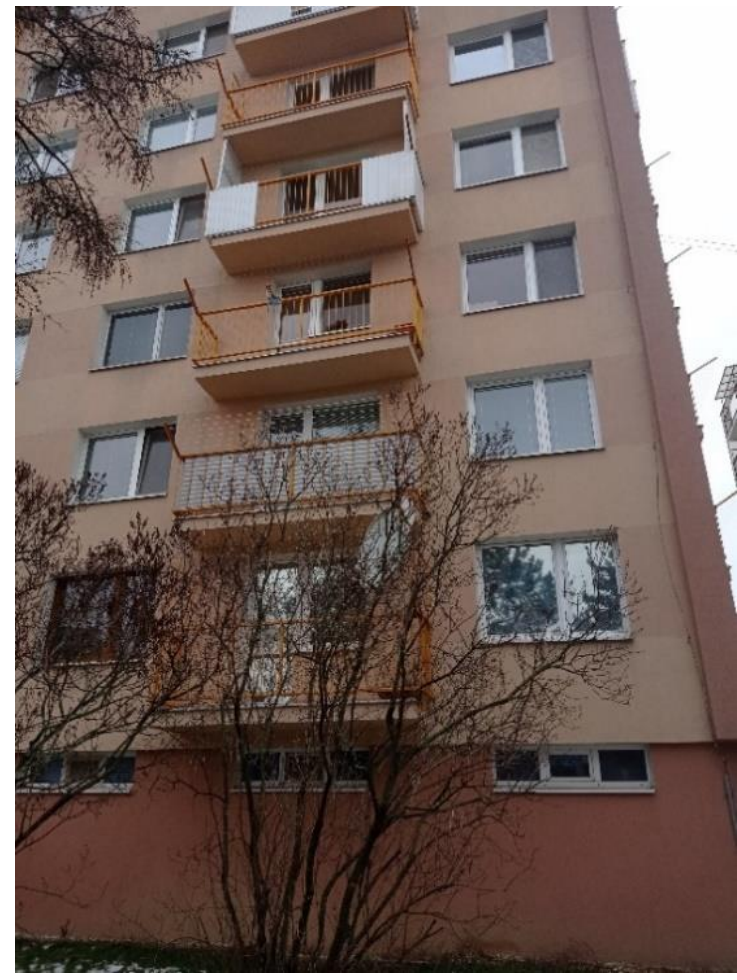

(a) view with balconies - south-oriented

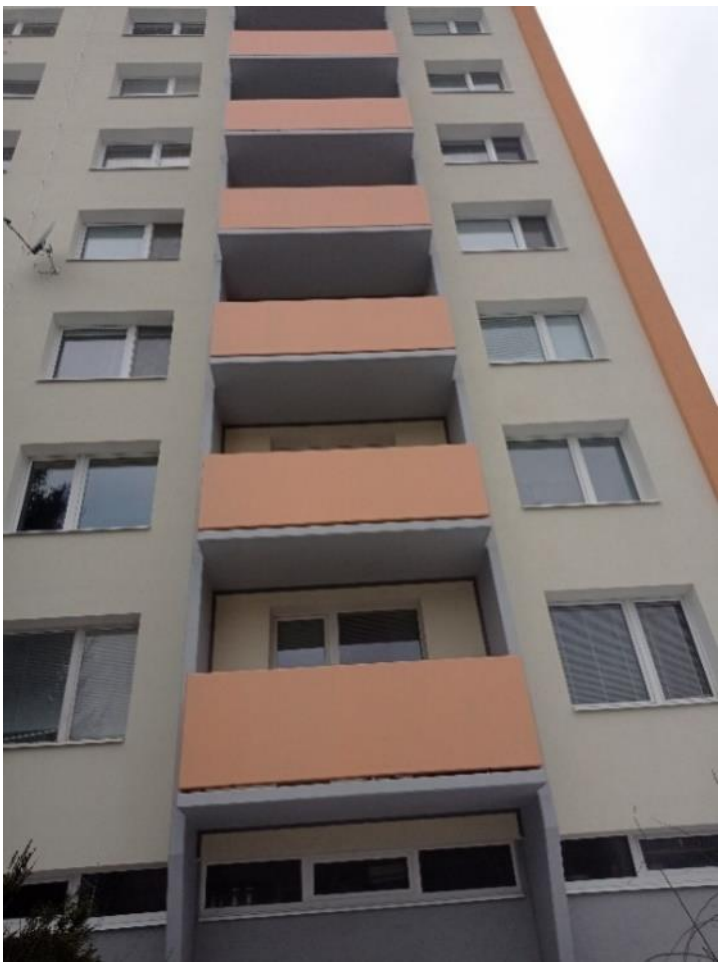

(c) view with loggias - south-oriented

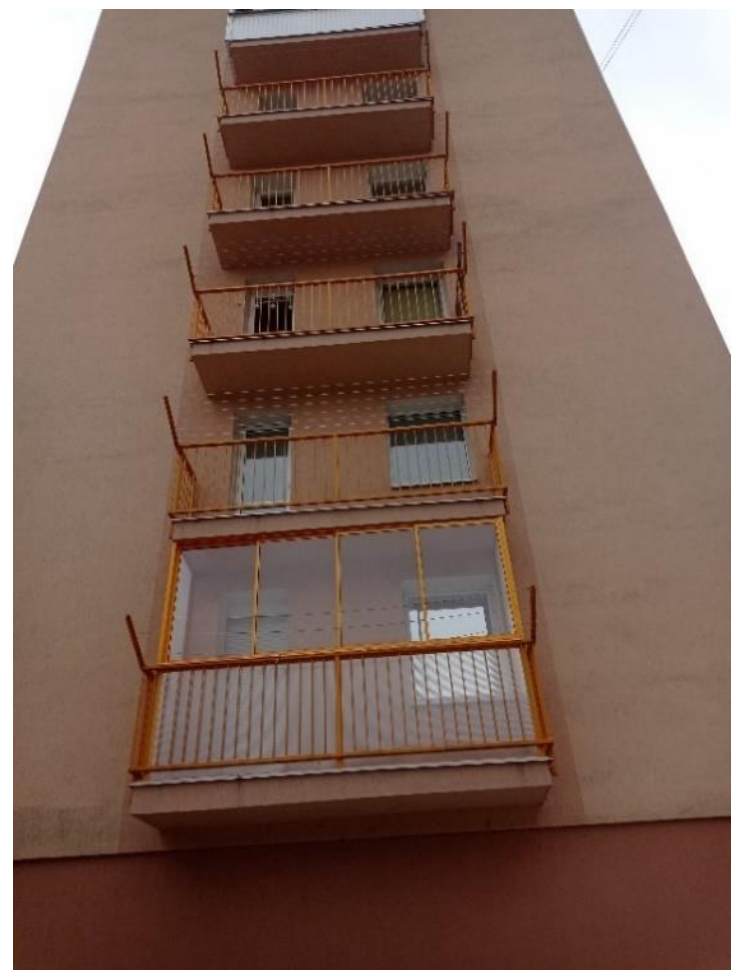

(b) view with balconies - east-oriented

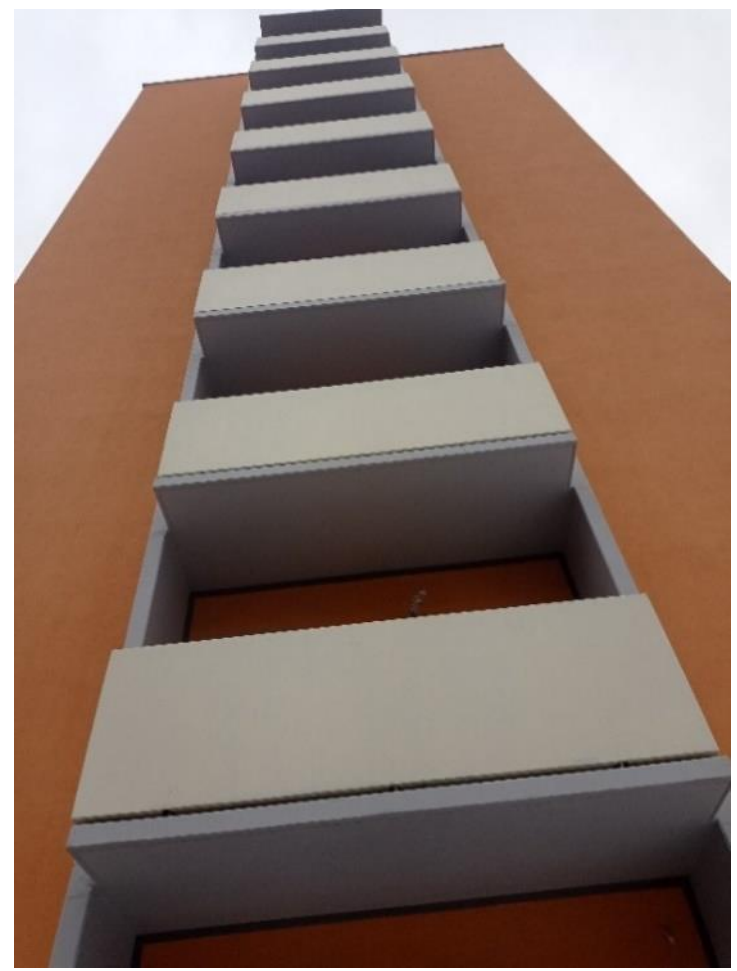

(d) view with loggias-east-oriented

Figure 4. View of the residential building $(\mathbf{a}, \mathbf{b})$ before reconstruction—balconies and $(\mathbf{c}, \mathbf{d})$ after reconstruction—loggias. 


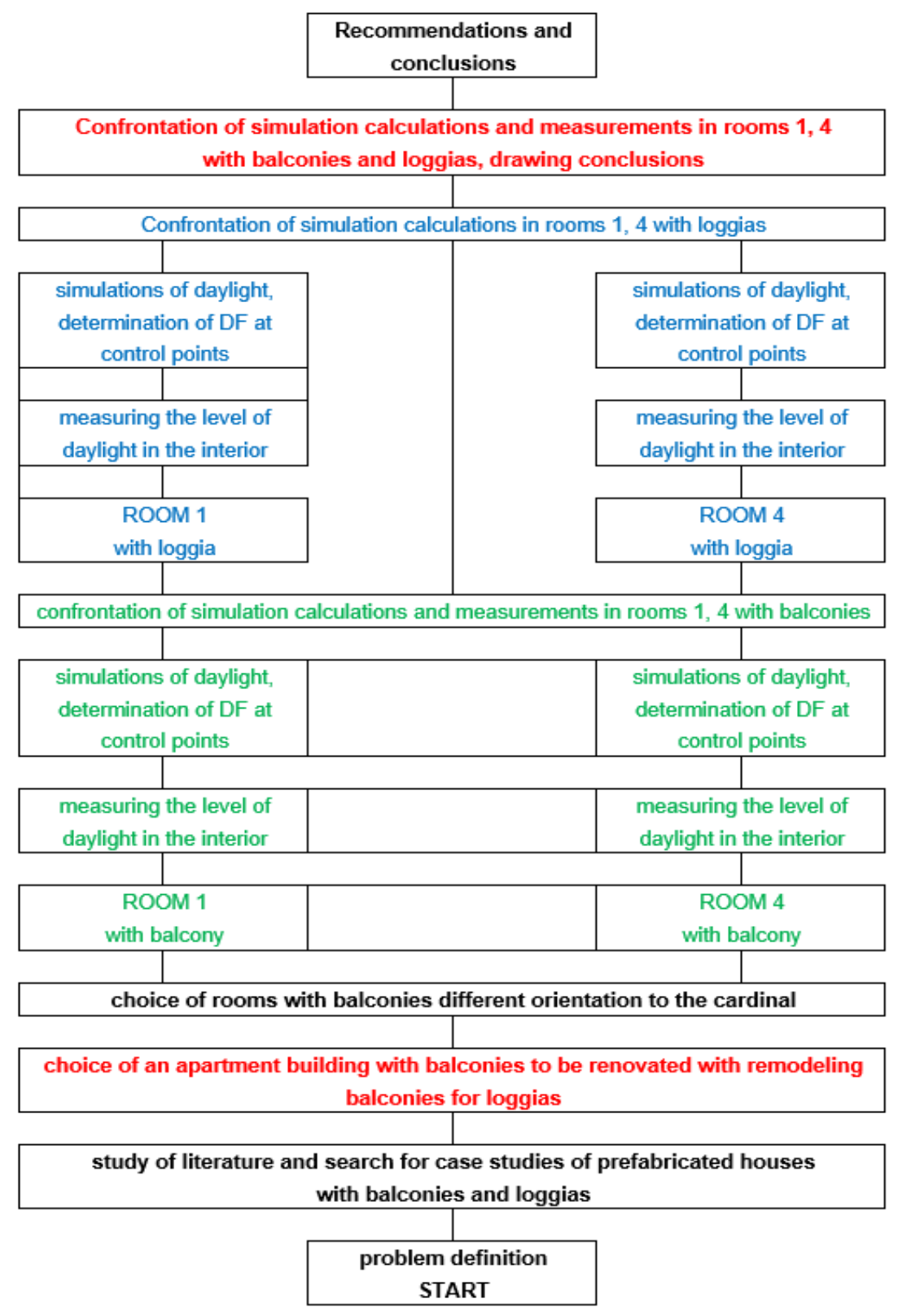

Figure 5. Flowchart of research methodology.

\subsection{Daylight Metrics}

In the study, were calculated following daylight metrics: daylight factor, illuminance, and uniformity.

The Daylight Factor (DF) is a form of static daylight performance metric. It is widely used and considered as one of the simplest methods to describe the amount of daylight received on a specific point in a room. The minimum and average daylight factors for rooms have been defined as $1.5 \%$ and $3 \%$, respectively $[30,31]$.

The illuminance (E) is the amount of light falling on a surface per unit area, measured in lux. It is measured at work plane height, and direct sunlight is excluded from the calculation. Recommended average values are 100-500 lux.

The uniformity $\left(\mathrm{U}_{0}\right)$ is defined as the ratio of the minimum DF to the average DF within the space. The daylight uniformity ratio of the rooms was analyzed in order to investigate how the daylight was distributed in each space. Standards require a uniformity of 0.4.

The authors used static metrics (DF) for the investigation. It is generally acknowledged that the standard daylight assessment method, used in this paper-the daylight factor- 
is being replaced by metrics based on absolute values of luminous quantities predicted throughout the year using sun and sky conditions derived from standardized climates. The move to more realistic daylighting measures represents a significant level of additional complexity both in the simulation of light quantities and in the reduction of simulation data to easy-to-understand metrics. The simulation component, at least for buildings with standard glazing materials, is reasonably well understood. However, there is no consensus on the composition of metrics, and their formulation is an ongoing area of active research. In addition, non-residential and residential buildings represent very different evaluation scenarios, and it is not yet entirely clear whether one metric could apply to both [51].

Residential architecture is one of the largest market segments in construction. However, attention in the field of daylight simulation is surprisingly low. This raises the question of whether existing daylight metrics are suitable for home design. In reference [52], a critical check of current climate-based daylight metrics in the context of residential architecture is provided. It has been found that existing workflows often overlook relevant aspects of daylight in living spaces, such as daylight and seasonal availability of daylight and access to direct sunlight. Therefore, the concept of a new, annual climate-based assessment framework, called the daylight residential score, is being introduced to overcome these shortcomings. There are some dynamic metrics:

- Useful Daylight Illuminance (UDI), but also

- Spatial Daylight Autonomy Maximum (sDAmax) measures the percentage of floor area that receives daylight above the required illuminance,

- Annual Sunlight Exposure(aSE) measures the percentage of floor area that receives more than a certain number of annual hours (typically 250) of direct light above a minimum threshold (typically $1000 \mathrm{~lx}$ ), or other [51,52]:

- Daylight Glare Index (DGI),

- CIE Glare Index (CGI),

- CIE Unified Glare Rating (UGR),

- Daylight Glare Probability (DGP),

- Direct Light Access (DLA),

- Residential Daylight Autonomy (RDA) plots,

- Residential Daylight Score (RDS).

Most of them take as a basis direct sunlight and the time of year data for its action in a specific environment and building. However, our task is to objectify the effect of the modification of the balconies on the loggias and to express what changes this will cause in the interior lighting under cloudy skies. This means only diffuse daylight is taken into account.

\section{Case Study-Rooms in Residential Building}

The elected residential building is located in the city of Kosice-west. The residential house is built in a panel construction system type T06B, which has a load-bearing system formed of reinforced concrete walls axially spaced by $3600 \mathrm{~mm}$. A protruding perimeter cladding of aerated concrete is suspended on the load-bearing walls. The house in the longitudinal direction has a three-story road. Perpendicular to the middle tract symmetrically from both sides are transverse walls with a modulus of $3.6 \mathrm{~m}$. One part of the terraced building (expansion unit) usually consists of five modules with a span of $3.6 \mathrm{~m}$. The house has seven floors. The evaluated rooms of the residential building used in the case study are located on the fifth floor of this selected building.

\subsection{Daylight Calculations}

Measurements were performed in selected rooms in Kosice (see Figure 2). Southoriented testing rooms on the fifth floor with interior dimensions $3.43 \mathrm{~m} \times 3.67 \mathrm{~m} \times 2.70 \mathrm{~m}$ (Room 1) and $4.78 \mathrm{~m} \times 3.43 \mathrm{~m} \times 2.70 \mathrm{~m}$ (Room 4) were selected (see Figure 6). The height of the parapet in both rooms is $900 \mathrm{~mm}$. Side-window dimensions are $1200 \mathrm{~mm} \times 1450 \mathrm{~mm}$ and the size of the balcony window is $850 \mathrm{~mm} \times 2250 \mathrm{~mm}$ (Room 1). Room 4, side- 
window dimensions are $1200 \mathrm{~mm} \times 1450 \mathrm{~mm}$ and the size of the balcony window is $850 \mathrm{~mm} \times 2250 \mathrm{~mm}$.

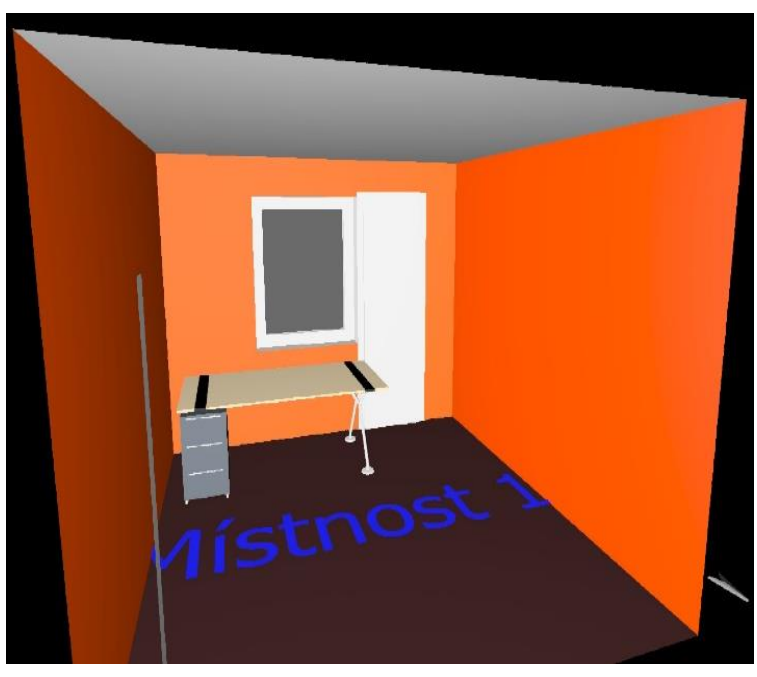

(a)

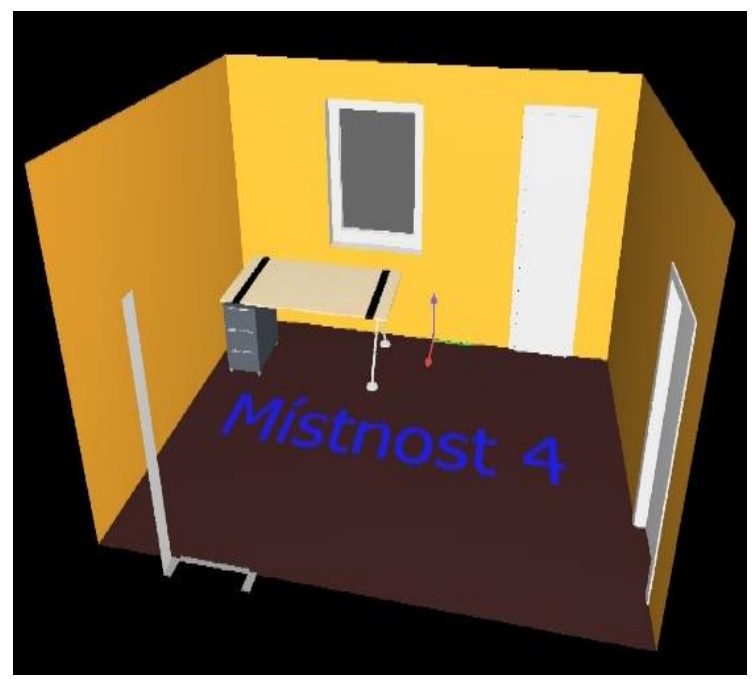

(b)

Figure 6. Interior of residential building (a) simulated model of Room 1: south-oriented; (b) simulated model of Room 4: east-oriented.

The fenestration systems were made of double glazing in plastic frame. For calculations, the following coefficients were considered: transmittance coefficient 0.8 , maintenance factor of glazing on the exterior surface 0.9 , maintenance factor of glazing on the interior surface 0.85 , reflectance factor of the ground 0.15 (dark ground). In all tested rooms, the color of the ceilings was white, the reflectance factor was 0.7 , and the reflectance factor of the floor was 0.45 . In Room 1 , the walls were orange, with a reflectance factor of 0.20 . In Room 4, the walls were yellow, with a reflectance factor of 0.30 (see Table 1). The window-to-wall ratio is $9.86 \%$ (Room 1 ) and $10.40 \%$ (Room 4 ) (see Table 2). The working plane was $0.85 \mathrm{~m}$ high (desk height). The light loss coefficient due to window construction was $\tau=0.64$. Neighboring objects did not shade the rooms. With the given lighting system, at the critical point of the functional place on the horizontal plane, the following values were required: minimum standard value of daylight factor, $\mathrm{DF}_{\min }=0.5 \%$ to $1.5 \%$; average daylight factor, $\mathrm{DF}_{\text {average }}=1.5 \%$ to $3 \%$; and uniformity of illumination more than 0.4 for given a visual task [53,54].

Table 1. Characteristic parameters of surfaces.

\begin{tabular}{cc}
\hline & Reflectance (\%) \\
\hline ceiling & 70 \\
floors & 45 \\
wall-orange & 20 \\
wall-yellow & 30 \\
\hline
\end{tabular}

Table 2. Window-wall ratio (WWR) and window-floor ratio (WFR).

\begin{tabular}{ccccc}
\hline & Area $\left(\mathbf{m}^{\mathbf{2}}\right)$ Window & Area $\mathbf{( m}^{\mathbf{2}}$ ) Walls & $\begin{array}{c}\text { Window-Wall } \\
\text { Ratio }\end{array}$ & $\begin{array}{c}\text { Window-Floor } \\
\text { Ratio }\end{array}$ \\
\hline Room 1 & 3.78 & 38.34 & 0.099 & 0.300 \\
Room 4 & 3.74 & 35.95 & 0.104 & 0.227 \\
\hline
\end{tabular}




\subsection{Daylight Measurements}

A minimum illumination of $300 \mathrm{~lx}$ is recommended for most of the room area meeting the target climate-based daylight factor and $500 \mathrm{~lx}$ for the areas where productive work is performed. On the selected day, the value of the outside light ranged from 2000 to $5000 \mathrm{~lx}$ in January. Measurement was performed at control points simultaneously with two lux meters (see Figure 7). An exterior horizontal illumination of $5000 \mathrm{~lx}$ was considered for the simulation program $[53,54]$.
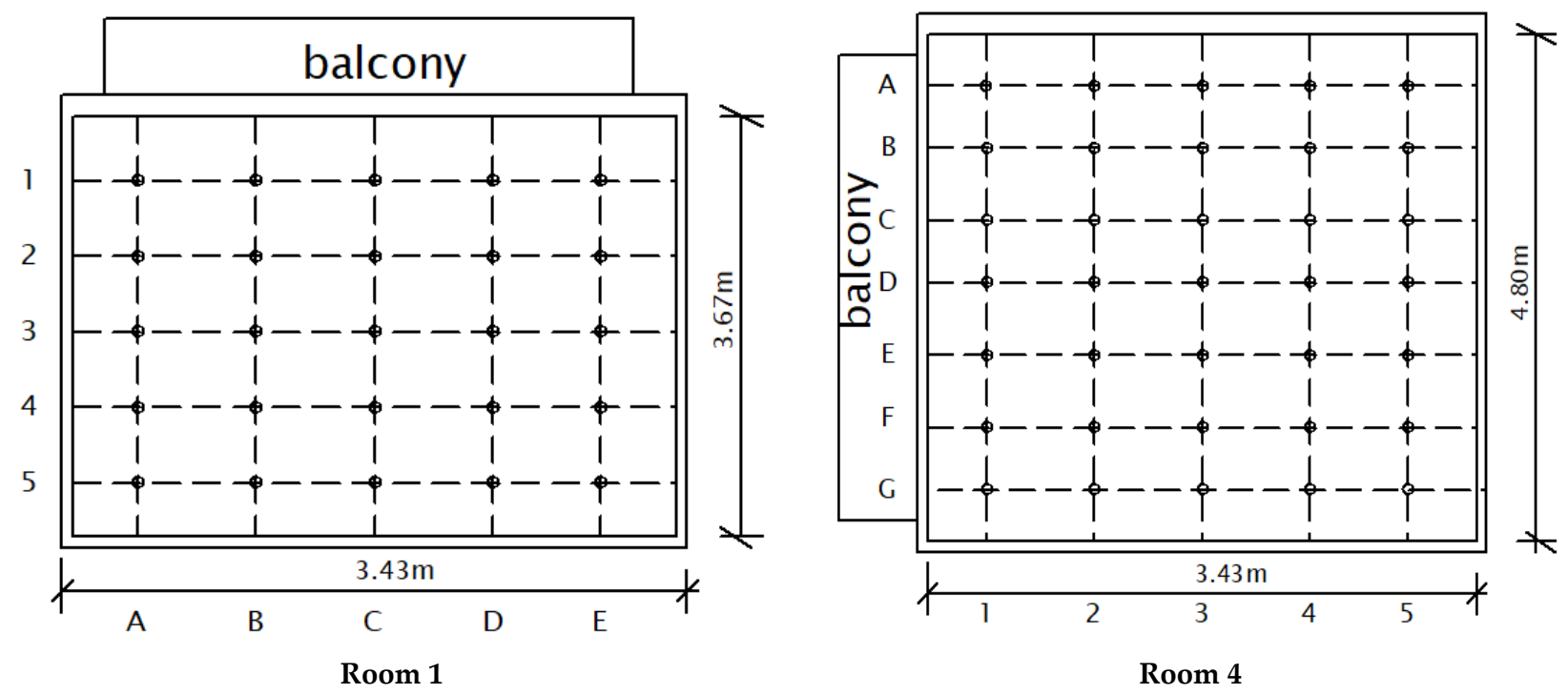

Figure 7. Situation-floorplan of rooms and control points for measurements and calculations.

The instruments used for measurement were two data loggers, ALMEMO 2690-10A, and an illuminance sensor ALMEMO FLA 623VL with the production number 15,061,543, and accuracy of $5 \%$.

Despite the fact that the manufacturer of this device provides this information on their catalog card, this information is not correct in terms of illuminometer metrology. It is not possible to determine the measurement error of the overall lighting instrument without knowing the spectral distribution of the measured light source $[55,56]$.

Various measurement procedures can be found in the literature and can also be affected by the influence of different photometric observers on the accuracy of the lux meter [57], the spectral correction of the detector used to measure the illumination [58], the register for evaluating the general photometric performance of photometers [59], and the relationship between measurement error and photometer power index [60]. Using artificial lighting influences of the quality of the spectral response of the photometric detector on the correction factors of the spectral mismatch of the white LED [61]. In Slovakia, the standard CSN 12464-1 applies to the lighting of workplaces [62]. A more detailed procedure of workplace lighting with a measurement methodology can be found in reference [63].

The measurement methodology in this case was followed according to Slovak standard "Measurements of daylighting" [64]. A more precise description of the measurement methodology is also in the literature, e.g., Darula [65]. A description of the entire methodology was published by the authors in Building and Environment [66] last year.

\subsection{Comparison of Measurement and Simulation Results}

Daylighting simulations were performed by DIAlux evo 9.1 with the model of tested rooms and two variants (balcony and loggia). The results of measured values of illuminance (E) and calculated DF from measured values can be seen in Tables 3 and 4 and Figure 8. 
Table 3. Results of daylight factor (DF, \%) from measured values.

\begin{tabular}{ccccc}
\hline & $\mathbf{D F}_{\min }$ & $\mathbf{D F}_{\max }$ & $\mathbf{D F}_{\text {average }}$ & $\mathbf{U}_{\mathbf{0}}$ \\
\hline Room 1-balcony & 0.60 & 4.74 & 1.82 & 0.33 \\
Room 1-loggia & 0.25 & 2.72 & 0.95 & 0.26 \\
Room 4-balcony & 1.00 & 3.50 & 1.70 & 0.59 \\
Room 4-loggia & 0.55 & 3.15 & 1.53 & 0.36 \\
Normed & 1.50 & - & - & 0.40 \\
\hline
\end{tabular}

Table 4. Results of measured values of illuminance (E, lx).

\begin{tabular}{cccc}
\hline & $\mathbf{E}_{\mathbf{m i n}}$ & $\mathbf{E}_{\mathbf{m a x}}$ & $\mathbf{E}_{\text {average }}$ \\
\hline Room 1-balcony & 20 & 142 & 55 \\
Room 1-loggia & 12 & 90 & 25 \\
Room 4-balcony & 45 & 150 & 76 \\
Room 4-loggia & 25 & 100 & 60 \\
Normed & $100-500$ & - & - \\
\hline
\end{tabular}

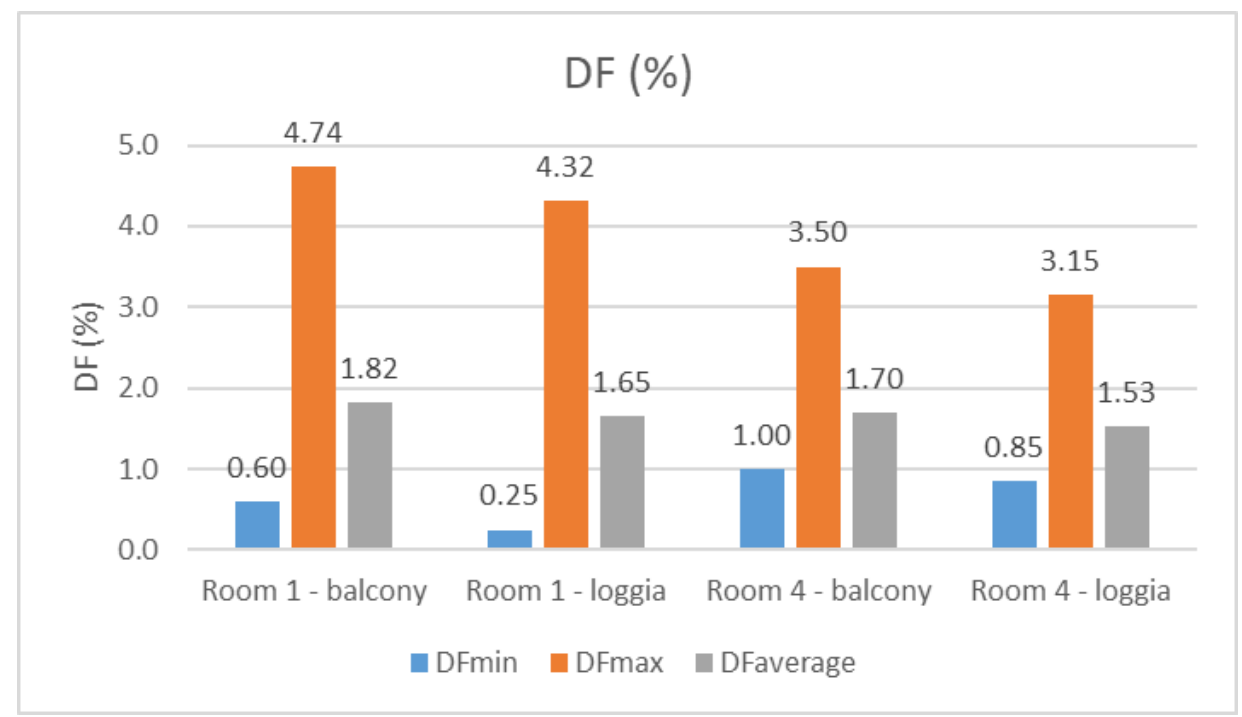

(a)

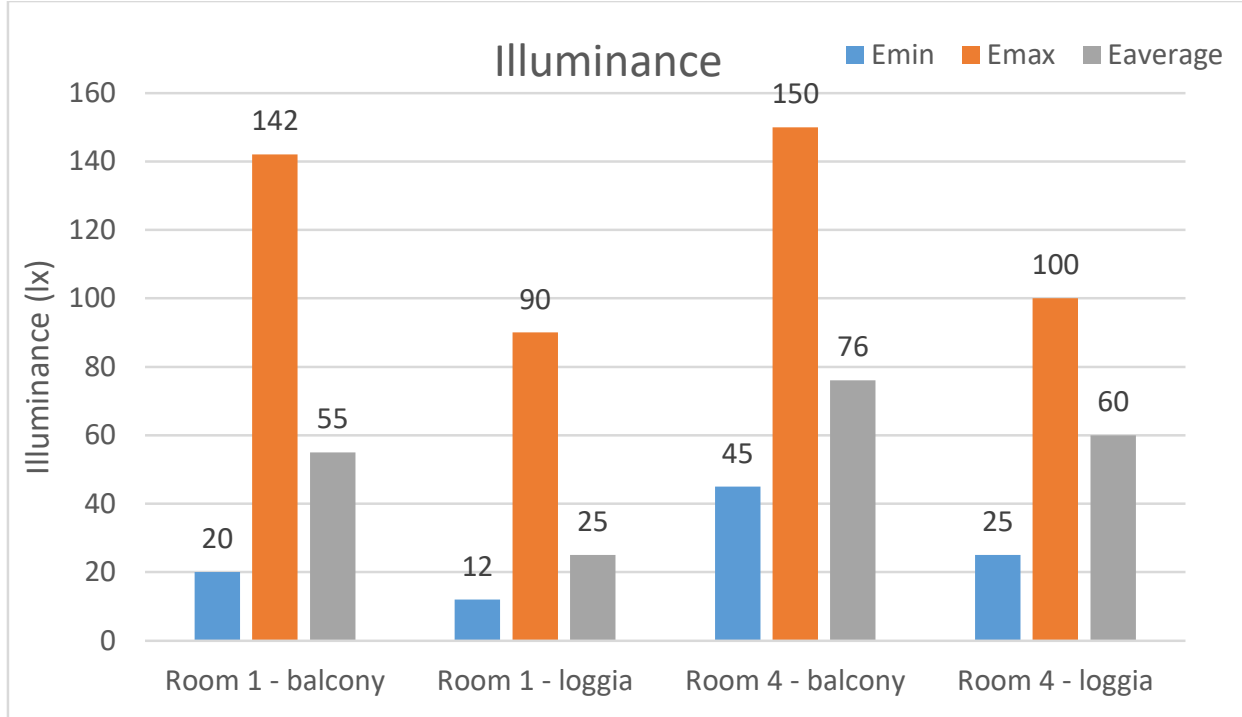

(b)

Figure 8. Results of (a) daylight factor (DF, \%) (b) illuminance (E, lx) from measured values. 
The results of simulated values for DF and illuminance can be seen in Table 5 and Figures 9 and 10. Isolines with the same illumination and DF can be seen in Figures 11-14.

Table 5. Results of DF calculated by the simulation program.

\begin{tabular}{ccccc}
\hline & $\mathbf{D F}_{\min }$ & $\mathbf{D F}_{\max }$ & $\mathbf{D F}_{\text {average }}$ & $\mathbf{U}_{\mathbf{0}}$ \\
\hline Room 1-balcony & 0.43 & 3.21 & 1.32 & 0.33 \\
Room 1-loggia & 0.31 & 1.51 & 0.63 & 0.49 \\
Standard deviation & 0.06 & 0.85 & 0.35 & \\
Room 4-balcony & 0.32 & 2.18 & 0.95 & 0.34 \\
Room 4-loggia & 0.08 & 1.91 & 0.75 & 0.11 \\
Standard deviation & 0.12 & 0.14 & 0.10 & \\
\hline
\end{tabular}

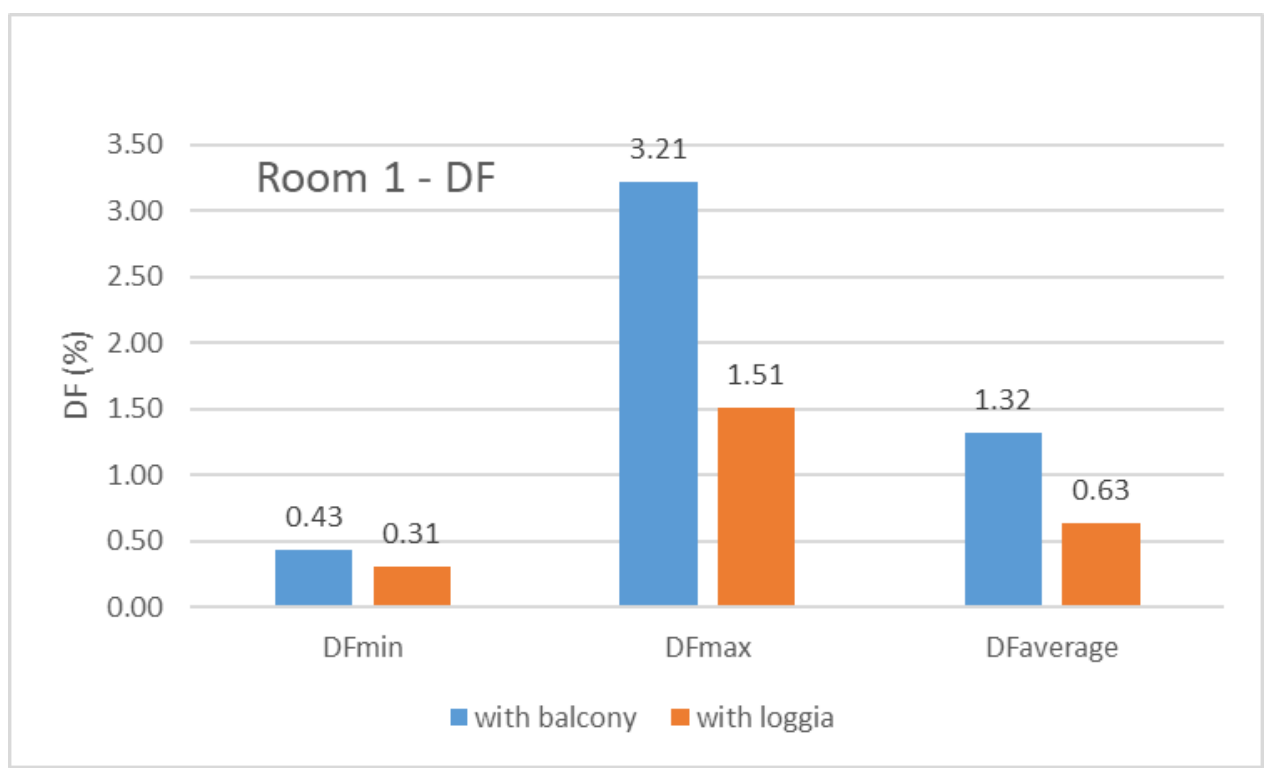

(a)

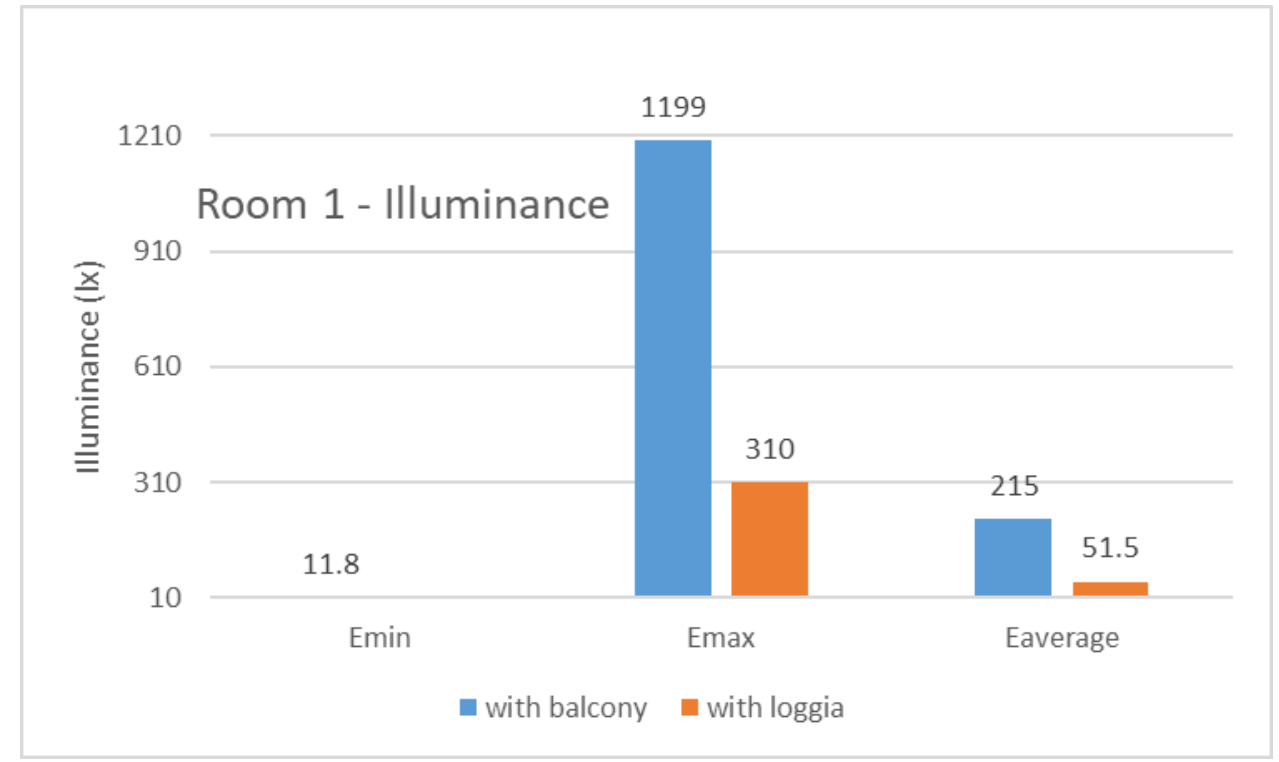

(b)

Figure 9. Results of simulated values of (a) DF (\%) and (b) illuminance-Room 1. 


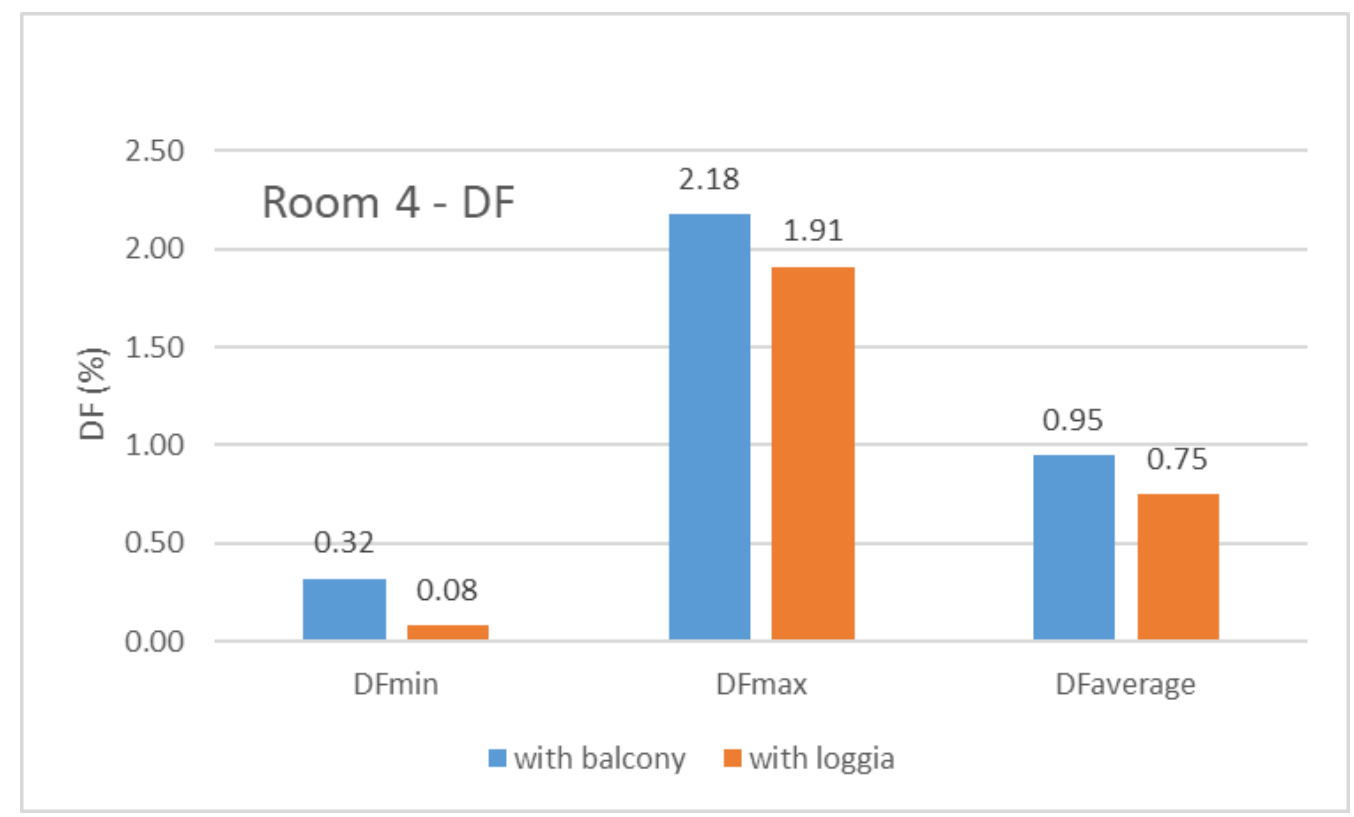

(a)

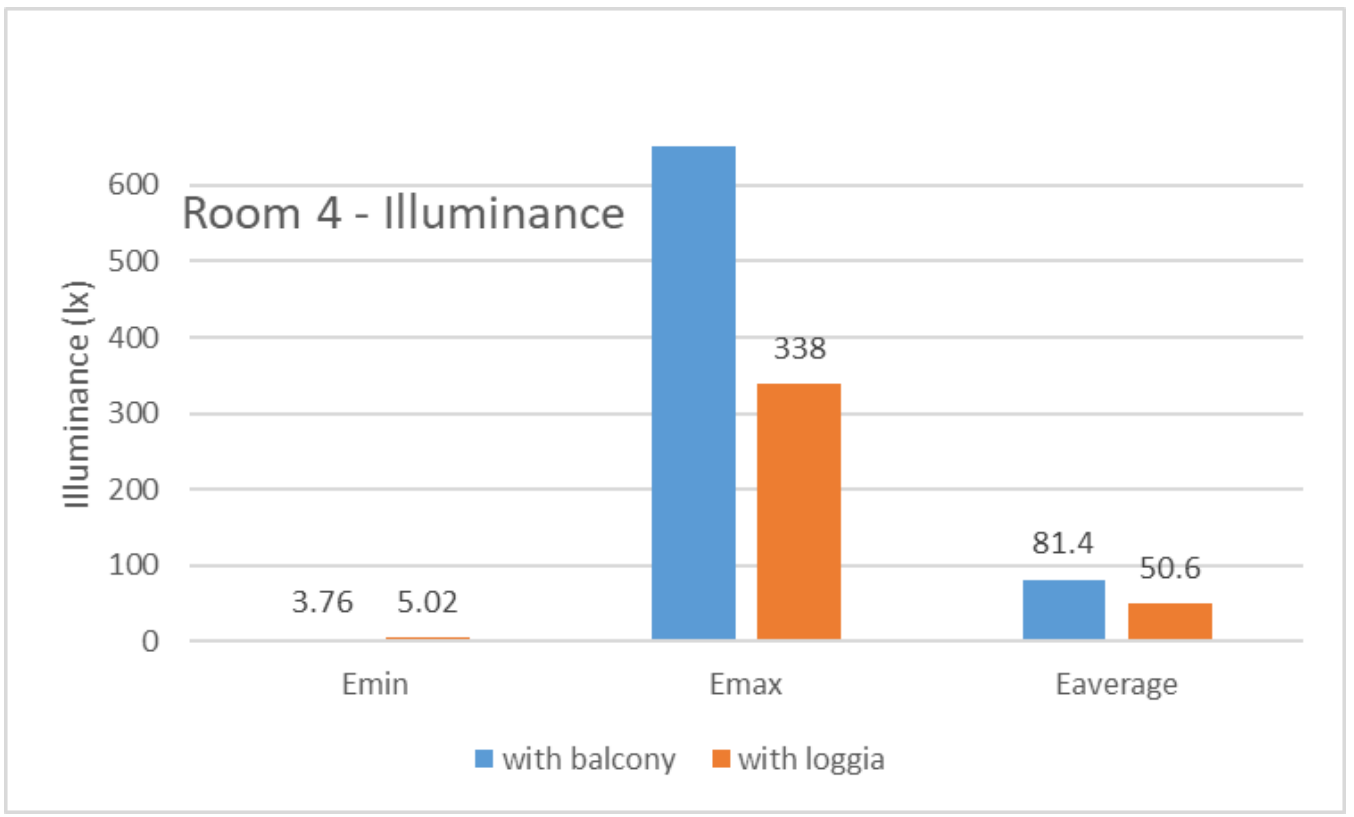

(b)

Figure 10. Results of simulated values of (a) DF (\%) and (b) illuminance (lx)-Room 4.

Figures 11c, 12c, 13c and 14c, show graphical dependences of simulated DF results in the section of the considered rooms at the considered points 1,2, 3, 4, 5 in individual rows A, B, C, D, E. It is interesting to see the decrease of DF, where it is clearly shown that in some places closer to the perimeter wall the DF values are lower when the position of observed points is at a greater distant from the wall.

In addition to these already presented results, the influence of color, position, and glazing was investigated in all cases. The results are interesting.

Although some authors report achieving a significant change in the indoor light climate by applying different colors on the loggia walls, in our observation, these changes were not significant. Due to the fact that diffuse light is considered, the influence of the color of the loggia walls on the lighting conditions in the interior was minimal. The values of the daylight factor changed only in hundreds. 


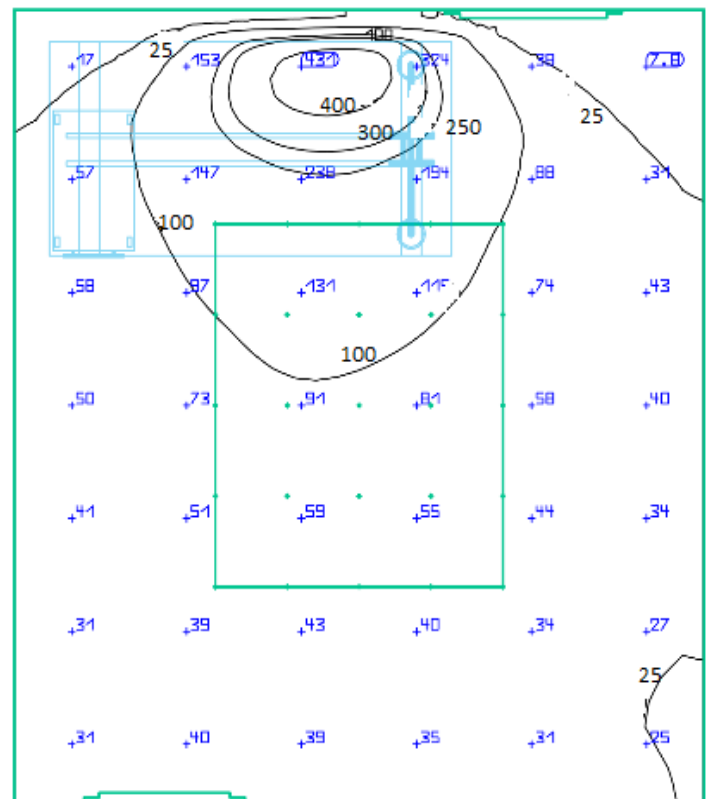

(a)

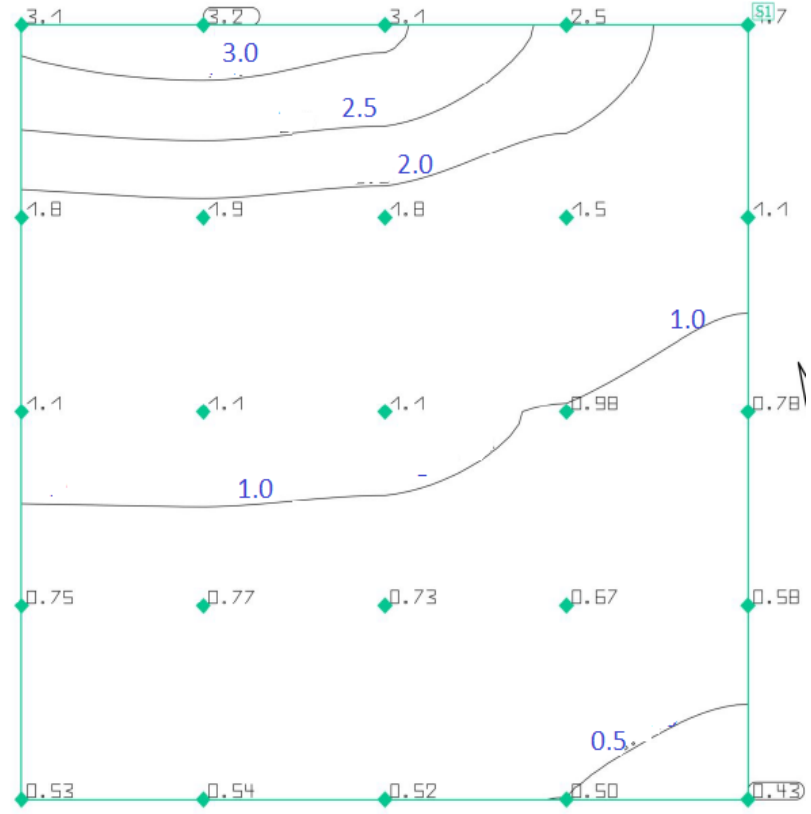

(b)

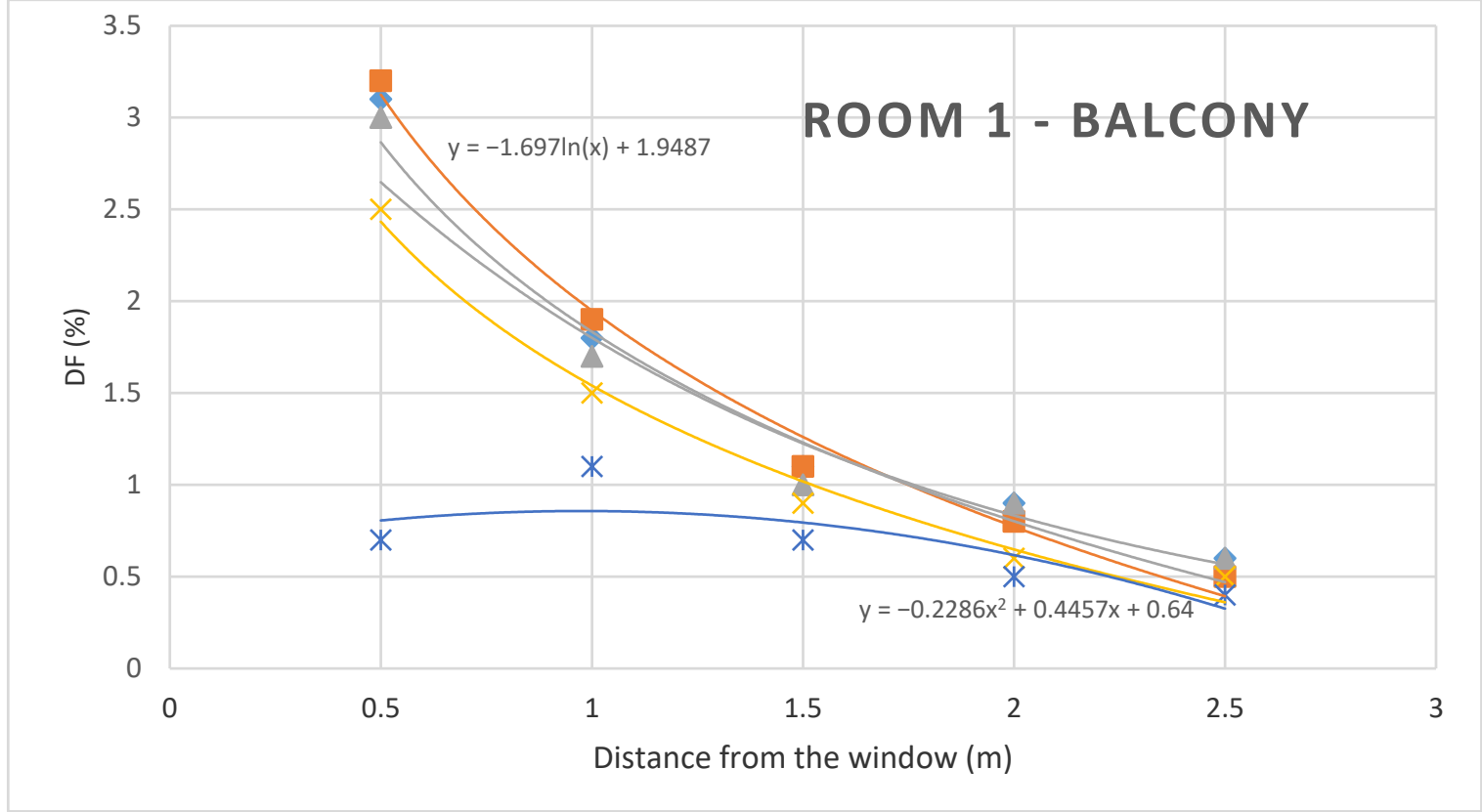

(c)

Figure 11. Results of (a) illuminance (lx) and (b) daylight factor (\%), Room 1-with balcony; and (c) the decrease of the DF at points remote from the transparent structure.

From this, it can be concluded that the influence of the color of the loggia walls on the conditions of DF in the interior is not large. This result was achieved in both rooms.

Interestingly, when only balcony boards (not loggias) were considered, the effect on the world is visible. Due to the influence of the reinforced concrete console of the slab above the apartment-in the orientation to the south (for Room 1) there is a difference for $\mathrm{DF}_{\min } 11 \%$ and in the orientation to the cardinal - the east (places for Room 4) there is a difference for $\mathrm{DF}_{\min }$ of up to $33 \%$.

In the graphs, parts of Figures 11a, 12ac, 13a and 14ac represent the level of daylight on the work plane in Rooms 1 and 4 in lux. In the graphs, parts of Figures 11b, 12b, 13b and $14 \mathrm{~b}$ represent the level of daylight on the work surface in Rooms 1 and 4, shown as DF (\%). 
The results for the change in the area of the translucent surfaces (window area) can be seen in Figure 15.

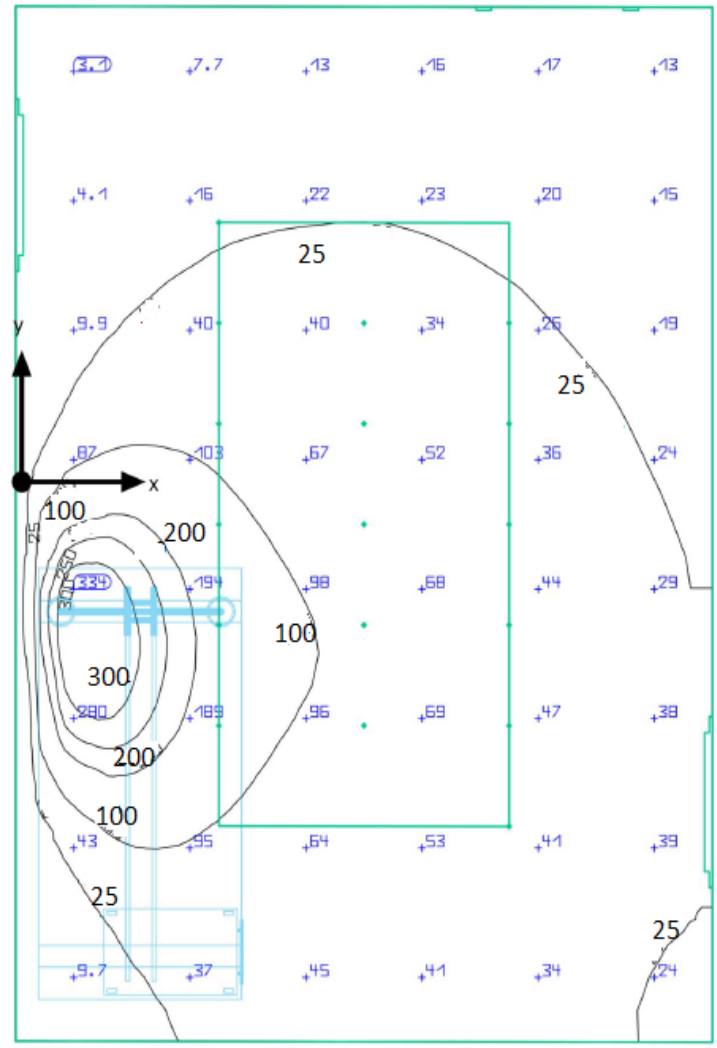

(a)

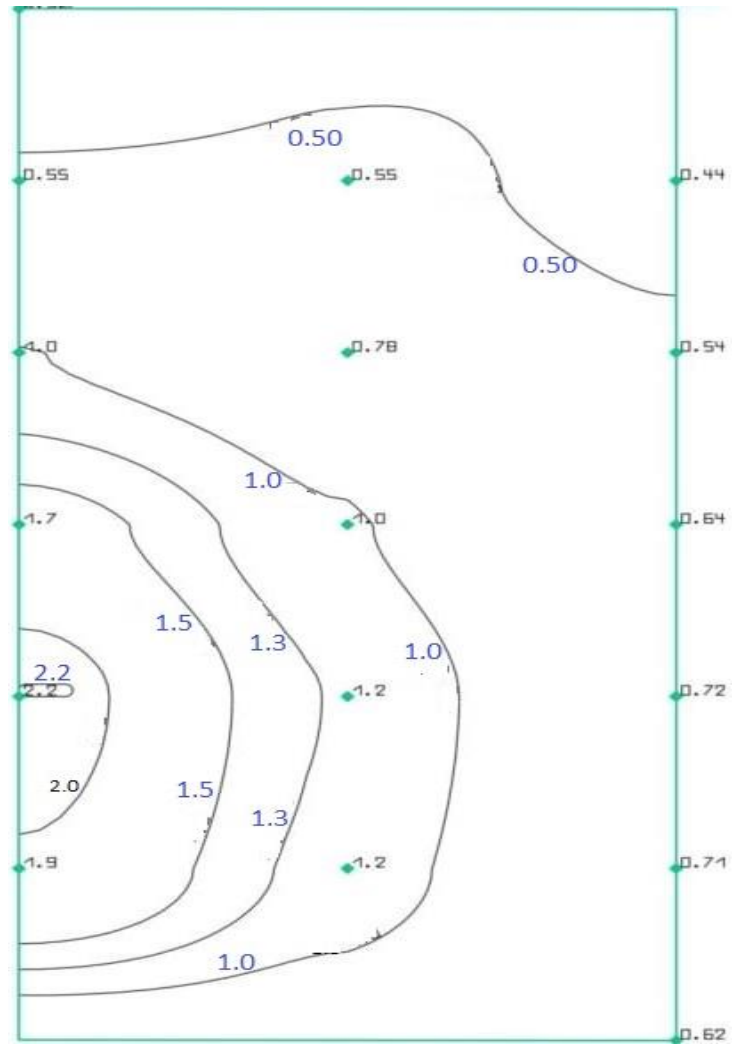

(b)

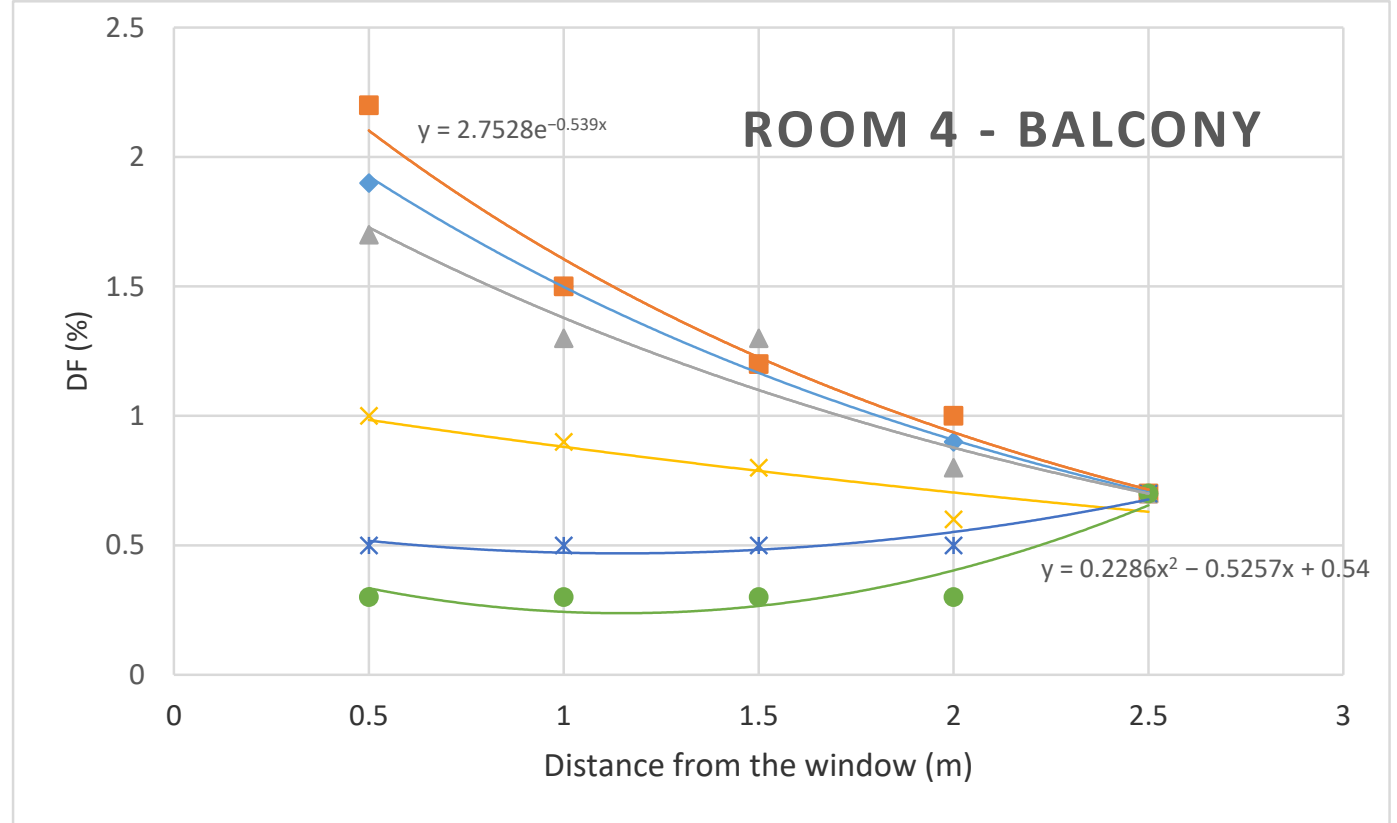

(c)

Figure 12. Results of (a) illuminance (lx) and (b) daylight factor (\%), Room 4-with balcony; and (c) decrease of the DF at points remote from the transparent structure. 


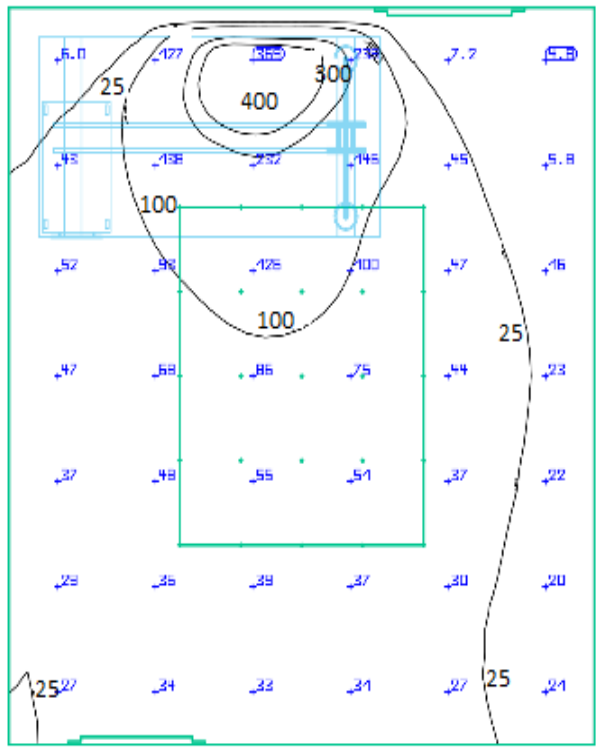

(a)

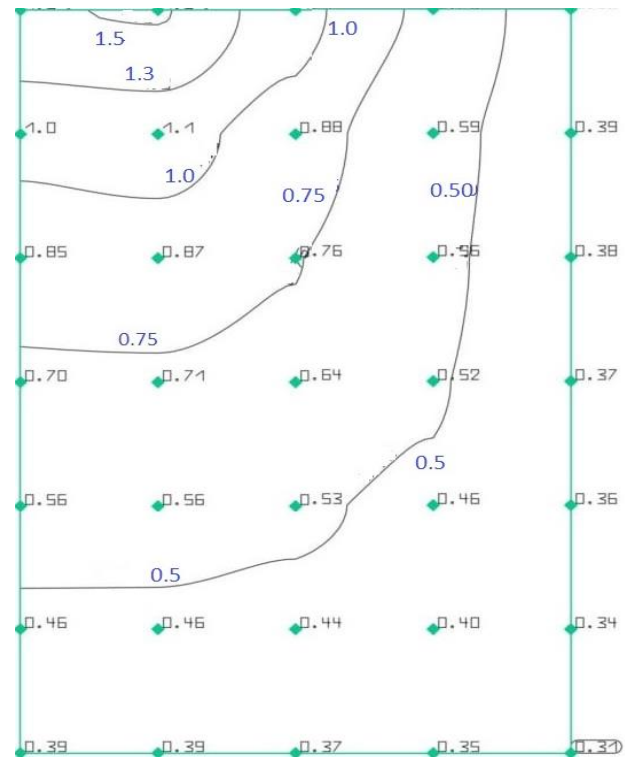

(b)

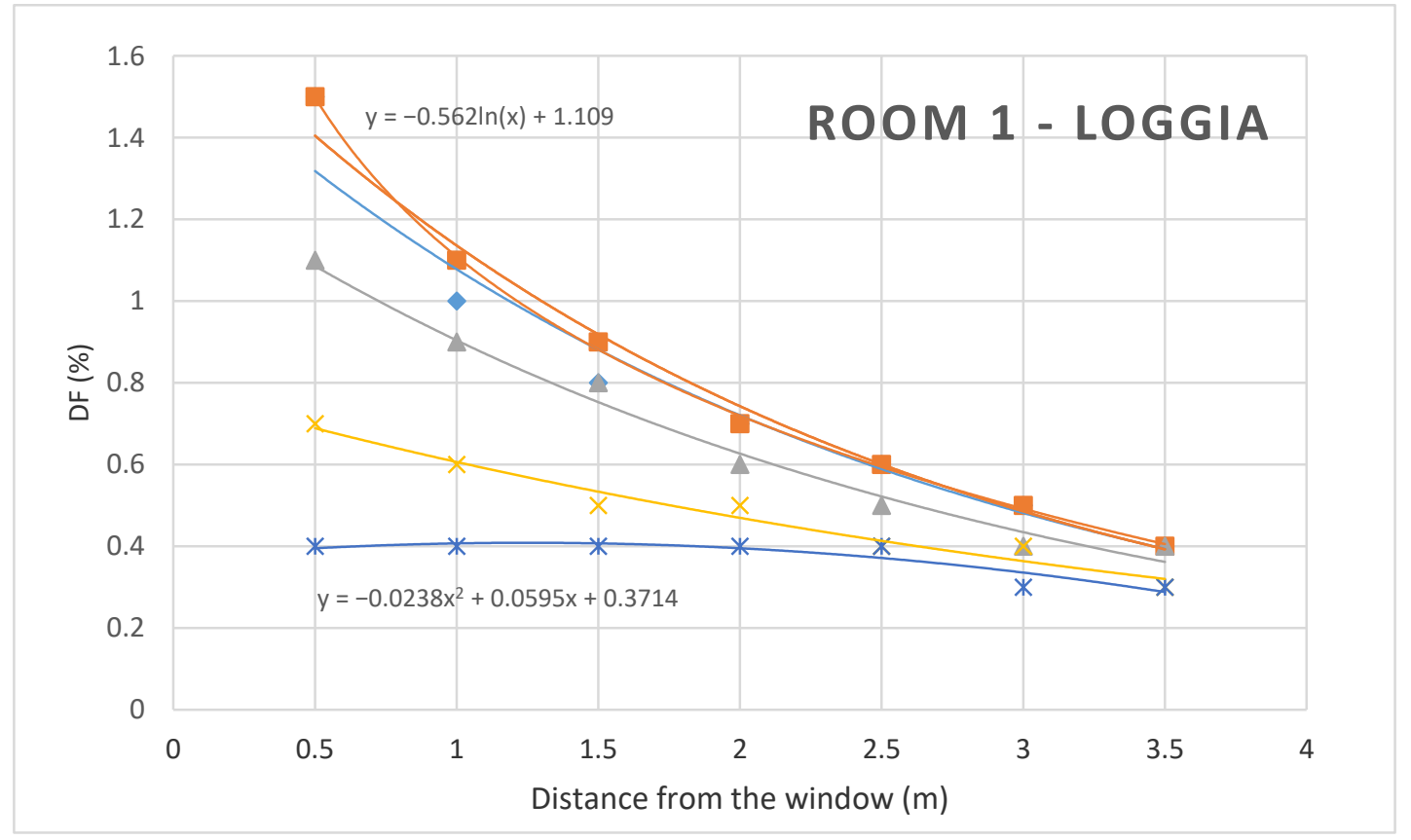

(c)

Figure 13. Results of (a) illuminance (lx) and (b) daylight factor (\%), Room 1-with loggia; and (c) decrease of the DF at points remote from the transparent structure. 


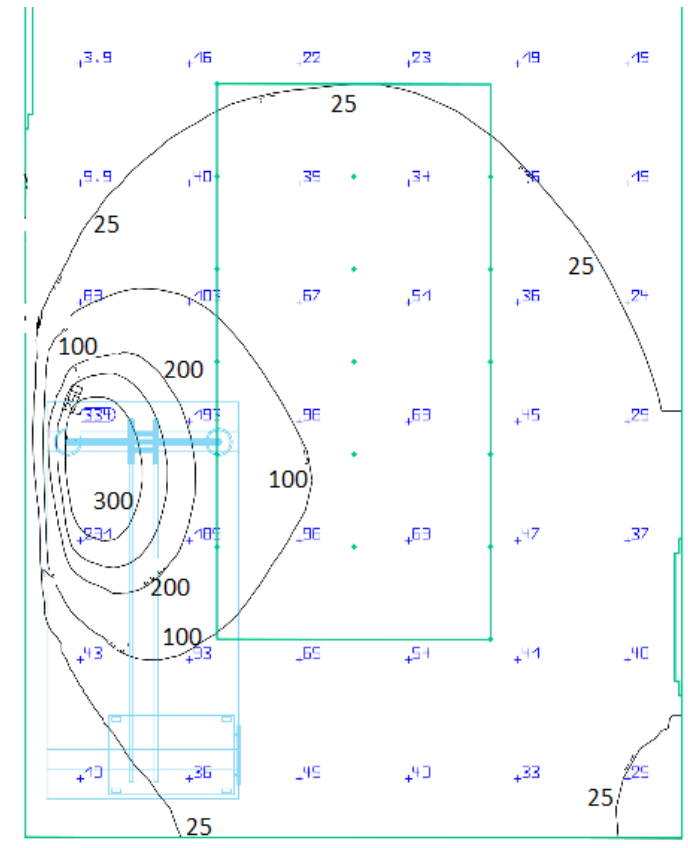

(a)

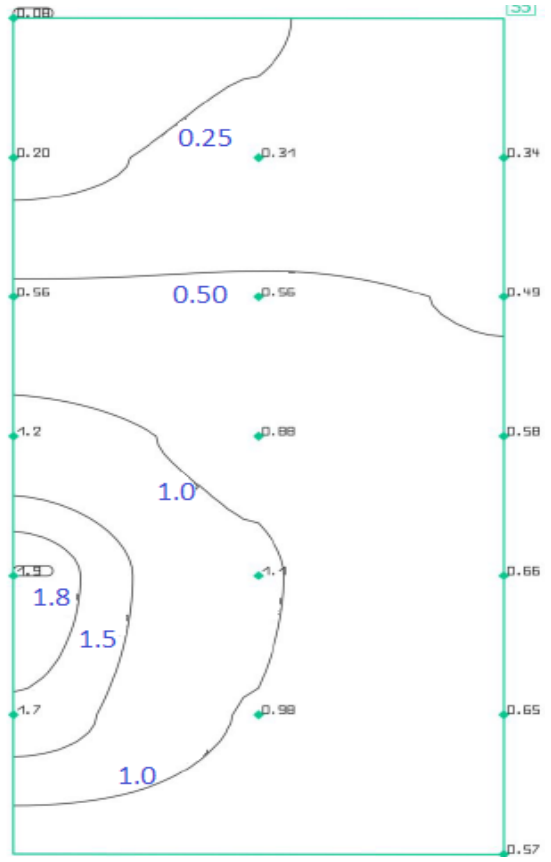

(b)

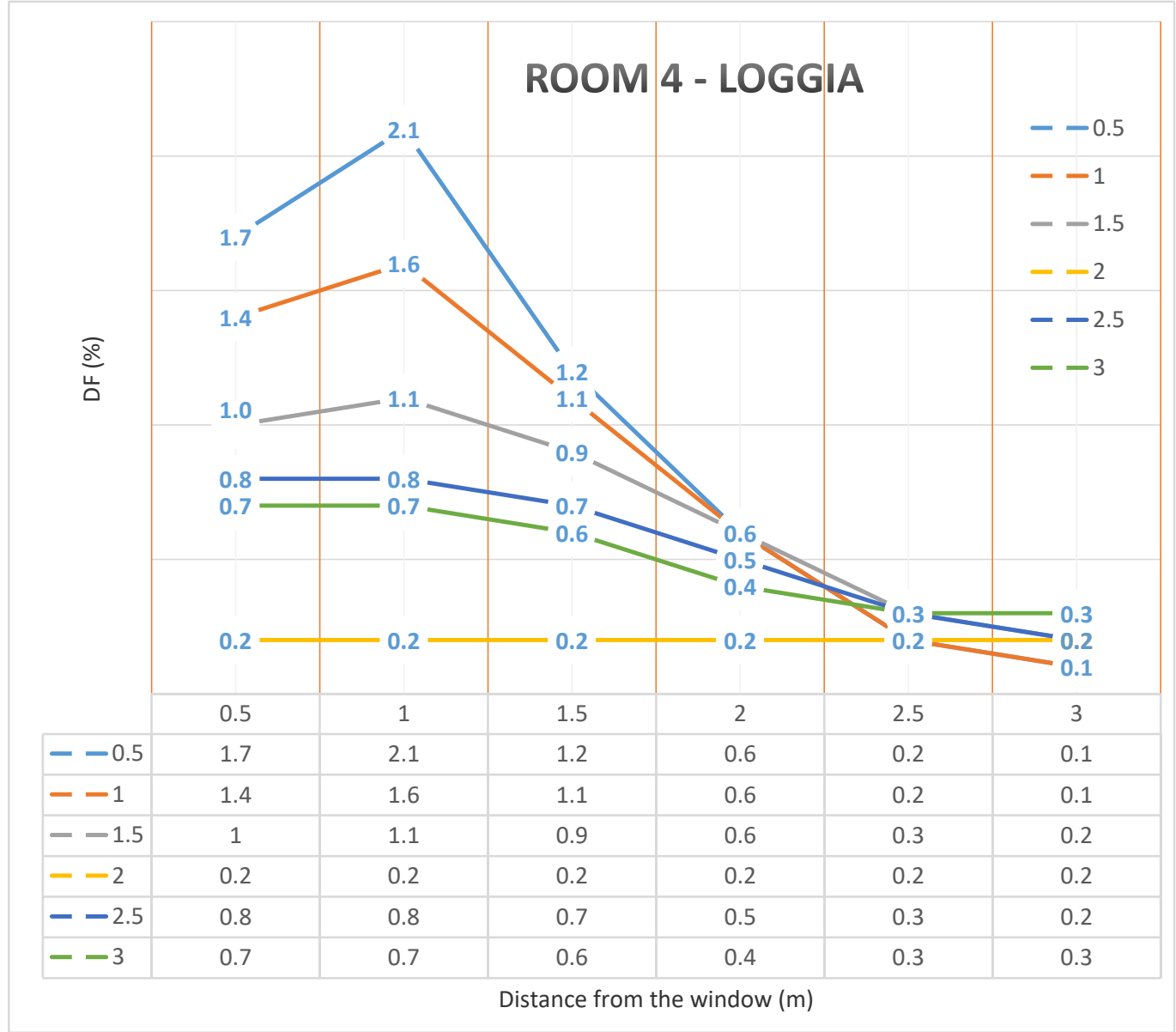

(c)

Figure 14. Results of (a) illuminance (lx) and (b) daylight factor (\%), Room 4-with loggia; (c) decrease of the DF at points remote from the transparent structure. 
The height of the window is the same in both Room 1 and Room 4, i.e., $1200 \mathrm{~mm}$, with a windowsill height of $900 \mathrm{~mm}$. If we widened the window by $100 \mathrm{~mm}$, we would get different results in cloudy skies, but the difference is not so great. The effect of the window area was measured by changing the width of the windows in both rooms.

The average DF naturally shows the biggest difference in the balcony in Room 1 and it varies from 1.32 to 1.95 . The smallest differences are in the same room, if instead of a balcony there is a loggia. The difference is very small; the average DF is from 0.63 to 0.79 . The same situation is repeated for $\mathrm{DF}_{\max }$. This is achieved again in Room 1 with a balcony and the smallest difference is in the same room with the loggia. Another is the setting with minimum DF values. Although the minimum DF value varies from 0.43 to 0.56 , the smallest difference in the minimum DF is achieved in Room 4 with a loggia, i.e., from 0.08 to 0.15 . The classification of these rooms into lighting classes depends on the activity performed.

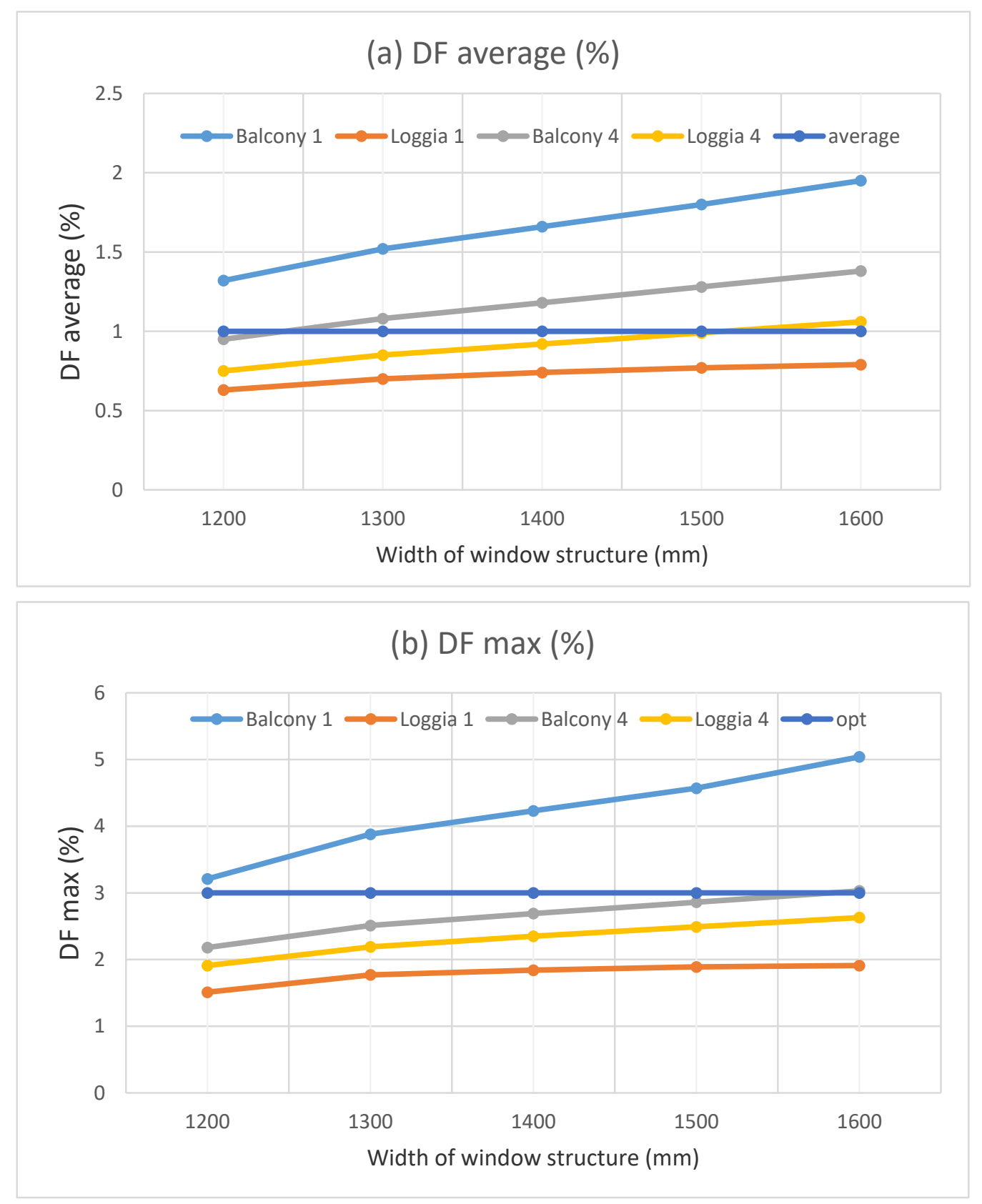

Figure 15. Cont. 


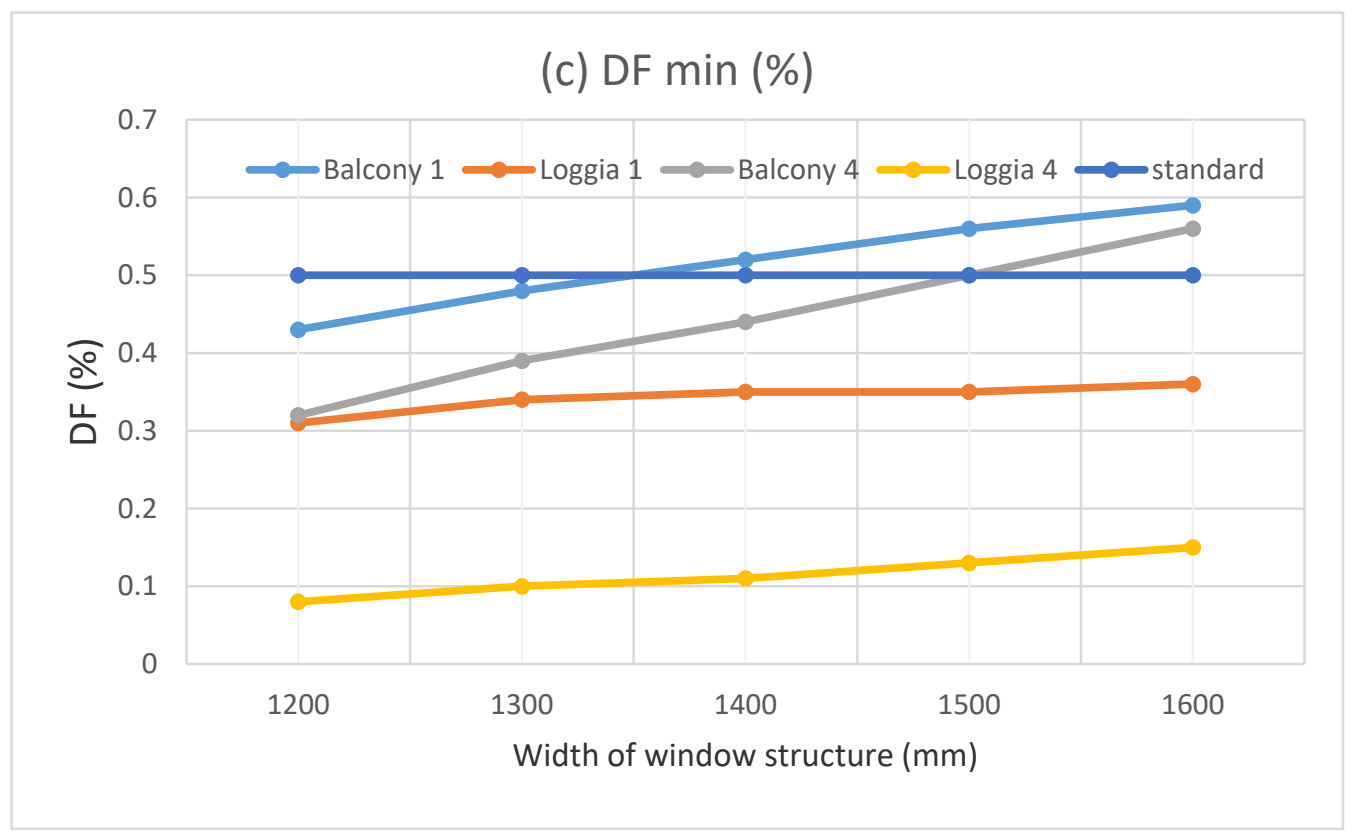

Figure 15. Results of DF (\%) for Rooms 1, $4(\mathbf{a}) \mathrm{DF}_{\text {average, }}(\mathbf{b}) \mathrm{DF}_{\max },(\mathbf{c}) \mathrm{DF}_{\min }$, and for rooms before and after reconstruction.

\section{Discussion}

This study examines the feasibility of renovating balconies into loggias to assess daylight. The evaluation of daylight availability was performed for both alternatives using measurements and a series of computer simulations DIAlux evo 9.1. The results of this study were evaluated in terms of daylight factor and lighting levels of the residential building according to daylight standards. The daylight factor is comparable in measurements and calculations. Boundary conditions were also found in the measurements, which were entered as inputs to computer simulations. The DF results were compared with the $\mathrm{DF}$ value standard. The results show that $\mathrm{DF}$, both on balconies and loggias, meets the expected values only in close proximity to the glazed areas.

The results show exactly that if the measured values have a DF value below the standard level (especially $\mathrm{DF}_{\text {min }}$ ), in the case of simulations they have DF values also below the standard. The distribution of the simulated DF values on the observation plane is shown in the Figures 11-14. When comparing the measured and normalized values, it can be stated that the $\mathrm{DF}_{\min }$ value is not met, but the values for the balconies are twice as high as those for the loggia.

In addition to the DF, the lighting level was taken into account in this study. The analysis of the lighting level shows the well-known fact that a higher lighting level is located at the windows and in the rooms with balconies. After the restoration of the balconies to the loggia, the level of lighting in the middle of the room will be reduced by almost $50 \%$, while on the sides of the room this level does not reach even $30 \%$ of the original lighting. The differences in Rooms 1 and 4 are slight.

For the resulting comparison of the decrease of the daylight factor in the distance from the windows, the graphs in Figures 11c, 12c, 13c and 14c were drawn in order to plot the graphic dependences. In Room 1 with a balcony in row " $\mathrm{C}$ " of the observation points, which is in the middle of the room through the window, the line is logarithmic, while in row " $E$ " close to the wall it is square (see Figure 11). The same curvature can be observed in Room 1 if the balcony is changed to a loggia, except that the DF values drop by about half (see Figure 13). In Room 4, the situation is different. If there is a balcony in the room, the results can be compared to those achieved in Room 1 only in the plane through the center of the window, where the graphical dependence is exponential, and in places close to the side wall as well as in the Room 1 quadratic (see Figure 12). If a balcony is created in 
Room 4, the results do not represent any functional dependence (see Figure 14). Near the window, the DFs are smaller than in more distant places.

Comparing the results in Rooms 1 and 4 with balconies and loggias is quite interesting. Figure 16 shows the results only for the center of the transparent opening (center of the room) at the observed height at the distances given in the previous sections. For Room 1 with balconies, it can be seen that the daylight factor drops sharply from the window, the resulting line acquires an exponential character. This is described by the blue equation. The daylight factor in Room 4 with a balcony has a similar course as in Room 1 . The slope of the line drop is smaller, but the course is also close to the exponential equation (red equation). The situation is different when applying a loggia. When creating partition walls on both sides of the balcony (left and right), the course of the daylight factor decrease is different. Finally, when looking for a functional dependence in Room 1 with a loggia, the course of the decline is logarithmic (green equation), and the situation in Room 4 with a loggia is quite complicated. Near the window, the DF is higher than at a more distant point. From a distance of about $1.5 \mathrm{~m}$, there is already a normal decrease in daylight. Finally, when testing multiple possibilities, the functional dependence in this case is quadratic (yellow line and yellow equation). These results show that the loggias are not successful in introducing light into the room. The numbers for lighting levels are still below the standard.

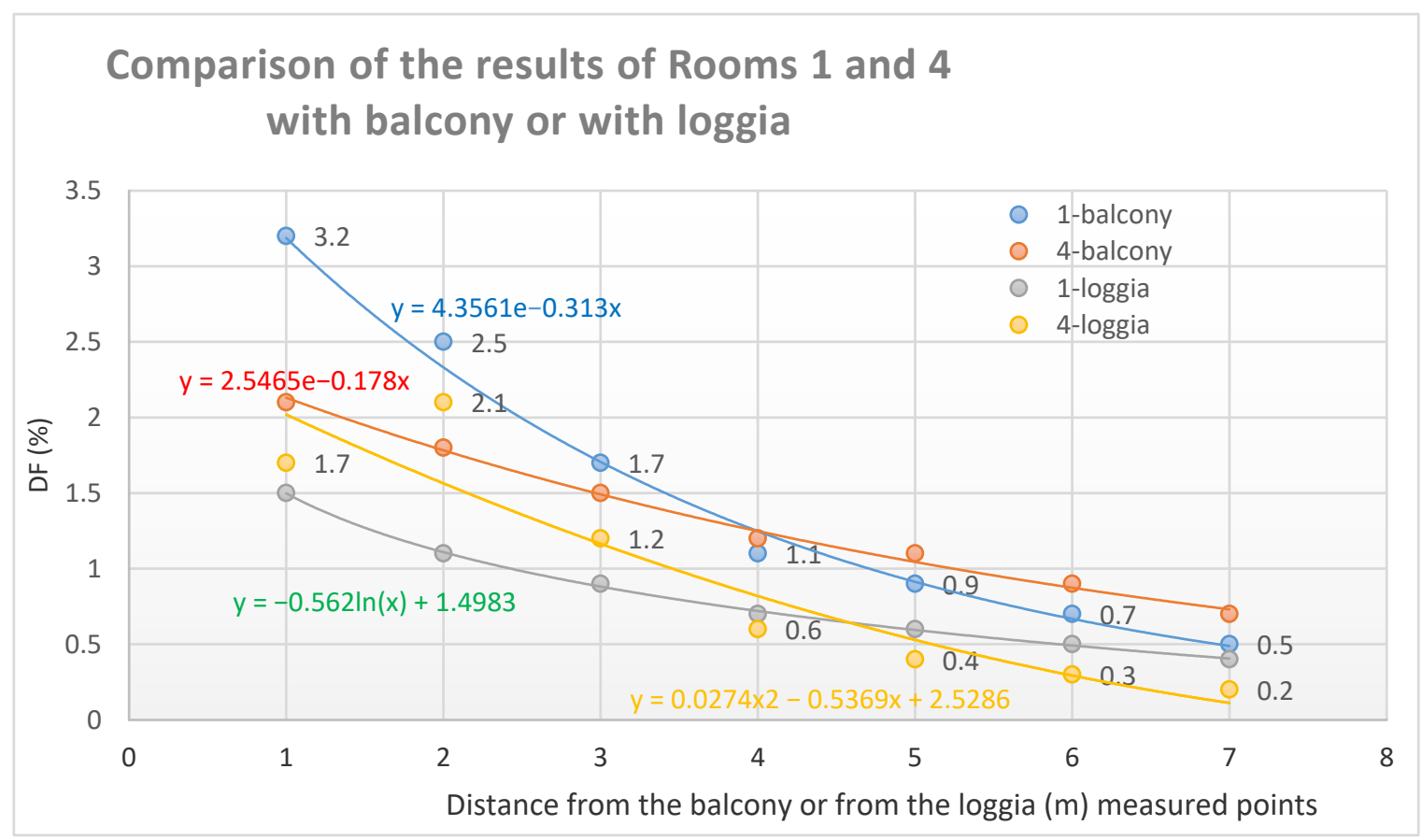

Figure 16. Results of DF (\%) for Rooms 1, 4 (blue line-Room 1 with balcony), (red line-Room 4 with balcony), (green line-Room 1 with loggia), (yellow line-Room 4 with loggia).

In further research, three influences on the level of DF after the change from a balcony to a loggia were observed. They were a change in the color of the loggia walls, the position to the cardinal, and the influence of the size of the glass part in the front wall, separating the room from the balcony (loggia). As already mentioned, the colors of the loggia walls do not have a significant effect on the resulting DF. The greater influence is the orientation of the room to the cardinal. Even though it is a cloudy sky, the brightness of the sky will increase or decrease the DF by $11 \%$ to $33 \%$.

The effect of the change of glazed surfaces on the resulting DF in the observed rooms is interesting in that this effect is different for balconies and loggias. In rooms with balconies, $\mathrm{DF}_{\text {min }}, \mathrm{DF}_{\max }$, and $\mathrm{DF}_{\text {average }}$ also increase by increasing the window area. In loggia rooms, 
these values are almost parallel lines (see Figure 15), indicating that these resulting values of $\mathrm{DF}_{\min }, \mathrm{DF}_{\max }$, and $\mathrm{DF}_{\text {average }}$ vary very little.

The impact of balconies or loggias is small for the evaluation criteria.

The good level of lighting was analyzed on the basis of the requirements for residential buildings according to national standards. The highest measured interior lighting at the farthest point was about 30-50 lx, which is below the standard value of $100 \mathrm{~lx}$. In both models, daylight reached high levels in areas near the windows and was reduced along the entire length of the room. However, $\mathrm{DF}_{\min }$ values were not reached for half of the room length.

\section{Conclusions}

In modern society, people spend most of their time indoors-the so-called indoor generation. This is especially true for this period of the pandemic, COVID-19, when in many countries there is a state of emergency, and it is not possible to go out. Daylight has a positive effect on human health and well-being. We can get daylight into the interior with transparent fillings. In this case, the visual connection of windows with the exterior through protruding elements from the facade of balconies and loggias was considered. The quality of lighting depends on many factors. People in many countries live in apartment block houses, where almost every apartment has a balcony or loggia. Reconstruction of balconies and loggias is one of the basic components of the renovation of apartment buildings. Balconies and loggias are a complex part of building design and provide considerable benefits to residential buildings. Going to the balcony is sometimes the only way to get outside for fresh air.

The aim of the study was to evaluate and compare the daylight availability in rooms with balconies and with loggias. The article compares two alternatives of façade elements: before reconstruction, with balconies, and after reconstruction, with loggias. The construction of the loggia adds to the building a different value in terms of architecture compared to the balcony. In terms of the entry of daylight into the interior, it is not the same case. The results show that the influence of loggias reduces the daylight factor by about half compared to the balconies.

In this study, a simulation program was utilized for models of rooms with balconies and loggias when considering the cloudy sky. The results of this study show the impact of balconies and loggias in residential buildings and their use for similar studies. The results from measurements show that the indoor light levels in rooms for both variants are below the standard. The daylight was insufficient to provide good illuminance, and the light was not uniformity distributed. The analysis showed that the balconies bring better results in letting daylight into the rooms compared to the loggias, but even these do not meet the required level of daylight (due to the top plate of the balcony in the apartment above). Reconstruction of the balconies improved the static and thermal properties but worsened the lighting conditions.

If we separate the balcony from the exterior on the right and from the left by a wall, we will create a safer space (loggia), but it will be worse for lighting conditions. We tried to graphically show the course of the decrease of the level of the daylight factor in the sections of the considered rooms. The results show that the decrease in the lighting level is different at the control points. Depending on how far the checkpoint is. In Room 1 it was a decrease of $30-50 \%$, while in Room 4 it was from $40 \%$ to almost $70 \%$. Therefore, when modifying the balcony to a loggia, it is necessary to keep these facts in mind. It is necessary to remember this and do everything we can to ensure safety and sustainability when using these spaces. As already mentioned, we must protect these areas, because sometimes these are the only areas where the occupant can be in contact with the outside environment. 
Author Contributions: Conceptualization, E.D. and D.K.; methodology, D.K.; software, E.D.; validation, B.D.; formal analysis, Z.M.; investigation, B.D.; resources, Z.M.; data curation, E.D.; writingoriginal draft preparation, E.D. and D.K.; writing—review and editing, Z.M.; visualization, E.D.; supervision, E.D. and D.K.; project administration, D.K.; funding acquisition, D.K. All authors have read and agreed to the published version of the manuscript.

Funding: This paper was elaborated with the financial support of the research projects VEGA 1/0674/18 and VEGA 2/0017/20 of the Scientific Grant agency, the Ministry of Education, Science, Research, and Sport of the Slovak Republic and the Slovak Academy of Sciences.

Institutional Review Board Statement: Not applicable.

Informed Consent Statement: Not applicable.

Data Availability Statement: Not applicable.

Conflicts of Interest: The authors declare no conflict of interest.

\section{References}

1. Cheong, C.H.H.; Kim, T.; Leigh, S.B. Thermal and daylighting performance of energy-efficient windows in highly glazed residential buildings: Case study in Korea. Sustainability 2014, 6, 7311-7333. [CrossRef]

2. Ali, M.A.D.; Daeung, D.K. A study of design variables in daylight and energy performance in residential buildings under hot climates. Energies 2020, 13, 5836. [CrossRef]

3. Westermann, K. Future Generations Face Health Risk from Life Indoors. Velux Media Centre, 2018. Available online: https: / / press.velux.com/future-generation-of-brits-faces-health-risks-from-life-indoors/ (accessed on 24 January 2021).

4. Westermann, K. Daylight Affects People's Sleep and Productivity, According to Global Survey. Velux Media Centre, 2018. Available online: https://press.velux.com/daylight-affects-peoples-sleep-and-productivity-according-to-global-survey/ (accessed on 24 January 2021).

5. Westermann, K. Are You Feeling Blue? Velux Media Centre, 2019. Available online: https://press.velux.com/are-you-feelingblue/ (accessed on 24 January 2021).

6. Sehar, A.; Priyadarsini, R. Investigating daylight in the apartment buildings in Melbourne. Infrastructures 2020, 5, 81. [CrossRef]

7. Kristensen, P.E. Daylighting technologies in non-domestic buildings. Int. J. Sol. Energy 1994. [CrossRef]

8. Mohapatra, B.N.; Kumar, M.R.; Mandal, S.K. Analysis of daylighting using daylight factor and luminance for different room scenarios. Int. J. Civ. Eng. Technol. 2018, 9, 949-960. Available online: http:/ / www.iaeme.com/IJCIET/index.asp (accessed on 24 January 2021).

9. Li, D.H.W. A review of daylight illuminance determinations and energy implications. Appl. Energy 2010, 87, 2019-2118. [CrossRef]

10. Schulzova, K.; Bošova, D. The quality of daylight in various types of residential buildings. EnviBuild 2019, 2019. [CrossRef]

11. Gochenour, S.J.; Andersen, M. Circadian effects of daylighting in a residential environment. Proc. IBPSA Conf. 2013, 70, 138-149. Available online: https:/ /infoscience.epfl.ch/record/153689 (accessed on 25 January 2021).

12. Reinhart, C.F.; Fitz, A. Findings from a survey on the current use of daylight simulations in building design. Energy Build. 2006, 38, 824-835. [CrossRef]

13. Šprah, N.; Košir, M. Daylight provision requirements according to EN 17037 as a restriction for sustainable urban planning of residential developments. Sustainability 2019, 12, 315. [CrossRef]

14. Ribeiro, C.; Ramos, N.M.M.; Flores-Colen, I. A review of balcony impacts on the indoor environmental quality of dwellings. Sustainability 2020, 12, 6453. [CrossRef]

15. Simm, S.; Coley, D. The relationships between wall reflectance and daylight factor. Architectural Sci. Rev. 2011, 54, 329-334. [CrossRef]

16. Lee, J.; Boubekri, M.; Liang, F. Impact of building design parameters on daylighting metrics using an analysis, prediction, and optimalization approach based on statistical learning technique. Sustainability 2019, 11, 1474. [CrossRef]

17. Cheung, H.D.; Chung, T.M. A study on subjective preference to daylit residential indoor environment using conjoint analysis. Build. Environ. 2008, 43, 2101-2111. [CrossRef]

18. Dogan, T.; Ye Chan, P. A new framework for residential daylight performance evaluation. In Proceedings of the Lux Europa 2009-11th European Lighting Conference, San Francisco, CA, USA, 7-9 August 2017. [CrossRef]

19. Aries, M.B.C.; Aarts, M.P.J.; Van Hoof, J. Daylight and health: A review of the evidence and consequences for the built environment. Light. Res. Technol. 2013, 47, 6-27. [CrossRef]

20. Edward, L.; Torcellini, A. A Literature review of the effects of natural light on building occupants. Natl. Renew. Energy Lab. Tech. Rep. 2002, 17-26. [CrossRef]

21. Ashrafian, T.; Moazzen, N. The impact of glazing ratio and window configuration on occupants' comfort and energy demand: The case study of a school building in Eskisehir, Turkey. Sustain. Cities Soc. 2019, 47, 101483. [CrossRef]

22. Andersen, M.; Gochenour, S.J.; Lockley, S.W. Modelling non-visual effects of daylighting in a residential environment. Build. Environ. 2017. [CrossRef]

23. Xue, P.; Mak, C.M.; Cheung, H.D. The effects of daylighting and human behavior $\mathrm{n}$ luminous comfort in residential buildings: A questionnaire survey. Build. Environ. 2014, 81, 51-59. [CrossRef] 
24. Acosta, I.; Campano, M.A.; Molina, J.F. Window design in architecture: Analysis of energy savings for lighting and visual comfort in residential spaces. Appl. Energy 2016, 168, 493-506. [CrossRef]

25. Konis, K.A. Novel circadian daylight metric for Building design and evaluation. Build. Environ. 2017, 113, 23-38. [CrossRef]

26. Fang, Y.; Cho, S. Design optimization of building geometry and fenestration for daylighting and energy performance. Sol. Energy 2019, 191, 7-18. [CrossRef]

27. Amoruso, F.M.; Udo, D.; Schuetze, T. Development of a building information modeling-parametric workflow based renovation strategy for an exemplary apartment building in Seoul, Korea. Sustainability 2018, 10, 4494. [CrossRef]

28. Hvass, T.; Jørgensen, H.; Volden, V. Bays, Balconies. Danish Architecture and Design Review. 2017. Available online: http: / / danishdesignreview.com/architecture/tag/balconies (accessed on 25 January 2021).

29. Arnesen, H.; Kolas, T.; Matusiak, B. A guide to daylighting and solar shading systems at high latitude. Proj. Daylight 2015. [CrossRef]

30. Brembilla, E.; Chi, D.A.; Hopfe, C.J.; Mardaljevic, J. Evaluation of climate-based daylighting techniques for complex fenestration and shading systems. Energy Build. 2019, 203, 109454. [CrossRef]

31. Seyedolhosseini, A.; Masoumi, N.; Modarressi, M.; Karimian, N. Daylight adaptive smart indoor lighting control method using artificial neural networks. J. Build. Eng. 2020, 29, 101141. [CrossRef]

32. Alwetaishi, M.; Taki, A. Investigation into energy performance of a school building in a hot climate: Optimum of window-to-wall ratio. Indoor Built Environ. 2020, 29, 24-39. [CrossRef]

33. Shi, X.; Abel, T.; Wang, L. Influence of two motion types on solar transmittance and daylight performance of dynamic façades. Sol. Energy 2020, 201, 561-580. [CrossRef]

34. Fabbri, K.; Gaspari, J.; Bartoletti, S.; Antonini, E. Effect of facade reflectance on outdoor microclimate: An Italian case study. Sustain. Cities Soc. 2020, 54, 101984. [CrossRef]

35. Prikulis, J. Private Outdoor Spaces-Balconies and Loggias in Latvia. 2019. Available online: https://nda.rtu.lv/en/view/23507 (accessed on 25 January 2021).

36. Bielek, B.; Szabó, D.; Čehel'ová, D. Development and Experimental Verification of Sliding Elements of Transparent Loggia Enclosures in High-Rise Building. In Applied Mechanics and Materials; Trans Tech Publications Ltd.: Brno, Czech Republic, 2017; Volume 861, pp. 3-10. [CrossRef]

37. Horn, V. Balcony structures. Pollack Periodica 2011, 6, 115-130. [CrossRef]

38. Dunichkin, I. Aspects of designing construction of balcony parapets with photoelectric cells. In MATEC Web of Conferences; EDP Sciences: Les Ulis, France, 2016; Volume 86, p. 02014. [CrossRef]

39. Kisnarini, R.; Krisdianto, J.; Indrawan, I.A. Contribution of Balcony on Thermal Comfort: Rusunawa Surabaya. Open House Int 2018, 43, 14-21. [CrossRef]

40. Nowak-Dzieszko, K.; Rojewska-Warchał, M. Influence of the balcony glazing construction on thermal comfort of apartments in retrofitted large panel buildings. Procedia Eng. 2015, 108, 481-487. [CrossRef]

41. Grudzińska, M. Glazed balconies as passive greenhouse systems-Potential of their use in Poland. Build. Serv. Eng. Res. Technol. 2016, 37, 555-572. [CrossRef]

42. Mésároš, P.; Spišáková, M.; Mandičák, T.; Čabala, J.; Oravec, M.M. Adaptive Design of Formworks for Building Renovation Considering the Sustainability of Construction in BIM Environment-Case Study. Sustainability 2021, 13, 799. [CrossRef]

43. Wróbel, K.; Kubiszyn, W. Balconies, loggias and different thin-walled units in large panel buildings. In Cost C16, Improving the Quality of Existing Urban Building Envelopes: Structures; IOS Press Ebooks: Amsterdam, The Netherlands, 2007; pp. 179-186.

44. Schulzová, K.; Bošová, D.; Černá, A.M. The Impact of Extending the Loggia of a Precast Panel Building on Daylight and Insolation of the Apartments. In Proceedings of the 2018 VII. Lighting Conference of the Visegrad Countries (Lumen V4), Trebic, Czech Republic, 18-20 September 2018; pp. 1-4. [CrossRef]

45. Kalousek, L.; Brzoň, R.; Fišarová, Z. Analysis of thermal bridges in loggias of pre-cast concrete apartment buildings. MATEC Web Conf. 2019, 279, 03008. [CrossRef]

46. Katunský, D.; Nemec, M.; Kamenský, M. Airtightness of buildings in Slovakia. In Advanced Materials Research; Trans Tech Publications Ltd.: Bäch, Switzerland, 2013; Volume 649, pp. 3-6. [CrossRef]

47. Maachi, I.N.; Mokhtari, A.; Slimani, M.E.A. The natural lighting for energy saving and visual comfort in collective housing: A case study in the Algerian building context. J. Build. Eng. 2019, 24, 100760. [CrossRef]

48. Nocera, F.; Lo Faro, A.; Costanzo, V.; Raciti, C. Daylight performance of classrooms in a mediterranean school heritage building. Sustainability 2018, 10, 3705. [CrossRef]

49. Costanzo, V.; Evola, G.; Marletta, L.; Pistone Nascone, F. Application of Climate Based Daylight Modelling to the Refurbishment of a School Building in Sicily. Sustainability 2018, 10, 2653. [CrossRef]

50. Tsangrassoulis, A.; Santamouris, M.; Asimakopoulos, D.; Tregenza, P.R. A method for the estimation of illuminances on surfaces of urban canyons with balconies in sunlit areas. Int. J. Light. Res. Technol. 1999, 31, 5-12. [CrossRef]

51. Mardaljevic, J.; Andersen, M.; Roy, N.; Christoffersen, J. Daylighting metrics for residential buildings. In Proceedings of the CIE 27th Session, Sun City, South Africa, 9-16 July 2011.

52. Dogan, T.; Park, Y.C. A critical review of daylighting metrics for residential architecture and a new metric for cold and temperate climates. Light. Res. Technol. 2019, 51, 206-230. [CrossRef]

53. STN 730580. Daylighting in Buildings, Part-1 Basic Requirements, 1986 Part-2; Daylighting of Residential Buildings; Slovak Republic Office of Standards, Metrology and Testing: Bratislava, Slovakia, 2000. 
54. EN 12464-1:2012. Light and Lighting; Lighting of Work Places-Part 1: Indoor Work Places; Slovak Republic Office of Standards, Metrology and Testing: Bratislava, Slovakia, 2012.

55. American Society of Heating, Ventilating, and Air Conditioning Engineers (ASHRAE). Guideline 14-2002. In Measurement of Energy and Demand Savings; Technical report; American Society of Heating, Ventilating, and Air Conditioning Engineers: Atlanta, GA, USA, 2002.

56. CIE 231: 2019. CIE Classification System of Illuminance and Luminance Meters. Available online: http://cie.co.at/publications / cie-classification-system-illuminance-and-luminance-meters (accessed on 25 January 2021).

57. Fryc, I.; Tabaka, P. The influence of different photometric observers on luxmeter accuracy for LEDs and FLs lamps measurements. Opt. Appl. 2019, 49, 345-354. [CrossRef]

58. Fryc, I. Spectral correction of a detector used in illuminance measurements. In Proceedings of the 11th Slovak-Czech-Polish Optical Conference on Wave and Quantum Aspects of Contemporary Optics, Stara Lesna, Slovakia, 21-25 September 1998; Volume 3820, pp. 343-348. [CrossRef]

59. Ferrero, A.; Velázquez, J.L.; Pons, A.; Campos, J. Index for the evaluation of the general photometric performance of photometers. Opt. Express 2018, 26, 18633-18643. [CrossRef]

60. Young, R.; Senft, M.; Tribes, D.; Peters, F. The relationship between measurement error and photometer cosine response performance index. Light. Res. Technol. 2016, 48, 26-34. [CrossRef]

61. Rosas, E.; Estrada-Hernández, A. Effect of photometric detector spectral response quality on white LED spectral mismatch correction factors. Appl. Opt. 2016, 55, 5267-5272. [CrossRef]

62. ČSN EN 12464-1. Světlo a osvětlení-Osvětlení pracovních prostorů-Část 1: Vnitřní pracovní prostory. 2004. Available online: http:/ / www.technicke-normy-csn.cz/360450-csn-en-12464-1_4_69656.html (accessed on 25 January 2021).

63. Dehoff, P. Quality criteria as part of the european standardization-the revision of en 12464-1 "Lighting of interior workplaces". Light Eng. 2010, 18, 30-31.

64. Standard ČSN 360014. Measurements of Daylighting; Czechoslovak Republic, Office of Standards, Metrology and Testing: Prague, Czechoslovak Republic, 1978.

65. Darula, S. Príspevok k meraniu vonkajšej zrovnávacej osvetlenosti podl'a ČSN 36 0011-2 (Contribution to the exterior reference illuminance measurement according to the ČSN 36 0011-2). In Proceedings of the Kurz osvětlovací techniky XXIII, Dlouhé Stráne, Czechia, 4-6 October 2004; pp. 15-18.

66. Dolnikova, E.; Katunsky, D.; Darula, S. Assessment of overcast sky daylight conditions in the premises of engineering operations considering two types of skylights. Build. Environ. 2020, 180, 106976. [CrossRef] 